\title{
PRÁCTICAS Y ESPACIOS MUSICALES DE UNA CIUDAD BURGUESA EN DESARROLLO: LOS ÚLTIMOS AÑOS DEL MADRID ISABELINO (1850-1868)
}

\author{
$M^{a}$ Encina Cortizo \\ Ramón Sobrino \\ Universidad de Oviedo
}

ORCID: https://orcid.org/0000-0002-5544-4827

ORCID: https://orcid.org/0000-0003-1705-0234

\section{RESUMEN}

El cambio que sufren las ciudades europeas tras las revoluciones liberales conforma unos nuevos modos de ocio y sociabilidad en los que la música juega un papel destacado. En una sociedad en proceso de cambio, se mantienen los salones románticos, pero serán la ópera y los nuevos géneros líricos los que conduzcan al teatro noche tras noche a la nueva burguesía que accede al poder político y económico, movida por su interés en sustituir a la antigua aristocracia. Compartimos algunas reflexiones sobre las prácticas musicales en el Madrid de mediados de siglo, en teatros, salones y sociedades, ocio para unos pocos según se desprende de un primer análisis de las condiciones y precios de acceso a estas diversiones. Asimismo, analizamos la aparición ya en la década de los sesenta de nuevos espacios -jardines, cafés-teatros...- y nuevas prácticas -sociedades de baile, teatro en secciones, conciertos al aire libre...- donde junto al género lírico aparece ya la música sinfónica, que contribuirán a generar un ocio barato y popular en la España posterior a la Revolución del 68.

Palabras clave: Madrid, teatros, prácticas musicales, espacios de sociabilidad

\section{ABSTRACT}

Music plays a prominent role in the new modes of leisure and sociability that appeared in European cities after the liberal revolutions. Though romantic salons remained a part of this changing society, it was opera and the new lyrical genres that attracted the new bourgeoisie to the theatre night after night as it assumed political and economic power, motivated by its desire to replace the old aristocracy. We share some reflections on musical practices in mid-century Madrid, in theatres, halls, and societies, which provided leisure for a few, as can be seen from an initial analysis of the conditions and prices of admission to these forms of entertainment. We also analyse the appearance in the 60s of new spaces - among them gardens and café-theatres - and new practices - such as dance societies, género chico, and open-air concerts - where symphonic music, which helped make leisure cheap and popular in Spain following the Revolution of '68, appeared alongside the lyrical genre.

Keywords: Madrid, theatres, musical practices, spaces of sociability

Madrid entre 1850 y 1868: "la entrada en escena de la multitud"1

La ciudad de Madrid vive durante el reinado isabelino una profunda transformación ligada a un ciclo de prosperidad económica. Aunque se incorpora tardíamente a la industrialización, en absoluto presenta una economía estancada, sino que, al igual que sucedió con ciudades como Lon- 
dres, París o Berlín -que además gozaron de una producción industrial de cierta importancia-, Madrid ejerció como capital del reino, encargándose "de organizar el funcionamiento de la nueva economía que las fábricas y el desarrollo que la industrialización estaban forjando"2.

A mediados de siglo, Madrid inicia, además, un despegue demográfico que, partiendo de los 206.00 habitantes de 1846, alcanza en 1860 los 300.000 habitantes $^{3}$; en 1877, los 397.816; y en 1900, el medio millón 4 . La principal razón de este crecimiento es la inmigración, un flujo constante de población ${ }^{5}$ que acude a la capital con aspiraciones de mejorar y que revierte la tendencia demográfica marcada todavía por un modelo antiguo con elevada mortalidad.

En 1860 se aprueba el Plan Castro para llevar a cabo el ensanche de Madrid ${ }^{6}$, iniciativa que procura nuevas viviendas para los emigrantes recién llegados y, a su vez, demanda más mano de obra, retroalimentando la llegada de nuevos obreros del mundo agrario, trabajadores no cualificados que acaban contratados como jornaleros en la construcción de inmuebles y renovación urbana, como la construcción de aceras, el adoquinado de calzadas,

la iluminación pública mediante faroles de gas (1847); la instalación del ferrocarril (1851); la traída de las aguas del Lozoya (1858) y la red de alcantarillado; los grandes mercados cubiertos y los pasajes comerciales; la instalación del tranvía (1871); las estructuras viarias y el flamante viaducto sobre la calle de Segovia (1872-1883); los nuevos edificios para el ocio, los grandes equipamientos urbanos, escuelas públicas y edificios singulares; [...] los jardines urbanos y los nuevos cementerios; o la iluminación eléctrica (1878)7.

Entre 1860 y 1905, la figura del jornalero, trabajador por cuenta ajena, es junto a la del artesano la más habitual entre la numerosa emigración que llegaba a Madrid. Los sueldos de estos trabajadores variaban desde los cuatro o cinco reales diarios de los obreros no cualificados, hasta los nueve reales diarios que podían cobrar cordeleros o vidrieros ${ }^{8}$.

También existió emigración femenina, que acaba contratada para el servicio doméstico, costumbre que "no sólo era propia entre la élite social de Madrid como en el caso de los criados varones, sino que estaba muy difundida entre las clases medias e incluso entre las franjas más privilegiadas de las clases populares" 9 . Las criadas vivían en la casa, circunstancia cómoda tanto para los amos como para las criadas -aquéllos, contaban día y noche con el servicio; y éstas resolvían tanto el alojamiento como la manutención ${ }^{10}$-, hecho que funcionaba como sueldo en especie al que en ocasiones se sumaba un escueto añadido mensual de entre 10 y 15 pesetas -entre 1,3 y 2 reales diarios. Amas de crías y nodrizas llegaban también al servicio de las clases más pudiente del Madrid isabelino, recibiendo, en ocasiones, además de pago en especie, un pequeño sueldo ${ }^{11}$ -en torno a tres reales diarios- que les permitía soñar con salir de la miseria ${ }^{12}$. Tras el matrimonio, la mayor parte de las mujeres se dedicaba a "sus labores" que apenas les dejaban tiempo libre; no obstante, existía un trabajo femenino por horas, a domicilio, complejo de rastrear ${ }^{13}$; según Rueda, las asistentas, lavanderas, planchadoras o costureras recibían en los años sesenta una media de tres reales diarios ${ }^{14}$.

A partir de la década de los sesenta, se inició la imparable expansión urbana. La burguesía, que deseaba modernizar Madrid a su gusto, transforma los espacios, "dejando ver los símbolos del nuevo poder de la sociedad liberal: el ayuntamiento y la diputación, los bancos, los teatros y plazas de toros, los nuevos mercados cubiertos o las viviendas"15, todo conectado por amplias avenidas, nuevos ejes urbanos, y adornado con plazas ajardinadas -squares- como las que propone el mismo Plan Castro.

La ciudad crece y sus nuevas dimensiones cada vez menos humanas-, demandan nuevos medios de transporte que conecten con el centro los barrios que el Ensanche iba sumando, naciendo ya en 1878 la primera compañía de tranvías que une Chamberí y Cuatro Caminos con la Puerta del Sol ${ }^{16}$. Así, poco a poco, "la revolución de las comunicaciones acortó los tiempos y ensanchó los espacios"17, acelerando el ritmo vital de aquel nuevo Madrid y ofreciendo nuevas profesiones "vinculadas a los transportes y a las comunicaciones que atrajeron a clases medias y altas en busca de una mejora social" ${ }^{18}$. 


\section{Música y sociabilidad en el Madrid de me- diados de siglo}

La música es un elemento omnipresente en la ciudad del siglo XIX; aparece tanto en contextos privados -salones, bailes o teatros particulares- como en espacios públicos -teatros, sociedades, parques y jardines, cafés o la propia calle-, actuando como un aura urbana común que difunde los repertorios de moda, bien sean ópera, zarzuela, canciones, música instrumental o danzas, en prácticamente todos los espacios de la ciudad. El arte musical es parte imprescindible de los ocios coetáneos, de forma que hablar de música supone hablar de sociabilidad; prácticas musicales y de ocio están íntimamente unidas y se retroalimentan. Así, los nuevos modos de producción musical que surgen a lo largo de la segunda mitad del siglo -desde el café-teatro al teatro por secciones, denominado castizamente "género chico" - acaban desarrollando también nuevas formas de sociabilidad.

La burguesía, nueva clase dirigente del estado liberal, sustituye en sus ocios a la antigua aristocracia y el resto de clases inferiores tratan de emular sus usos y costumbres urbanas en un interesante proceso de mímesis que ningún arte revela mejor que la música: se trata de una verdadera ósmosis social -en término de Marrast- entre la nobleza tradicional y la clase media que ha logrado ascender socialmente gracias al dinero ${ }^{19}$.

Los industriales, banqueros, inversores de bolsa y políticos que dominaban la España Isabelina y la convirtieron "en un país industrial y permeable a las corrientes culturales europeas" 20, ocuparán a partir de la década de los cuarenta el espacio antaño dominado por la nobleza de cuna y sus acciones obedecerán, por tanto, a su interés por devenir en la nueva aristocracia: compraban títulos nobiliarios, construían imponentes residencias en las calles más importantes del nuevo Madrid -caso del Marqués de Salamanca y su nueva residencia en Recoletos-, vestían a la moda, acudían al coiffeur, alternaban en cafés y teatros, paseaban por los nuevos espacios de ocio urbano, viajaban a los balnearios y a disfrutar de los "baños de ola", perpetuaban su imagen en daguerrotipos y fotografías..., en resumen, exhibían su riqueza desde su privilegiada atalaya social. Estos nuevos ricos abrazaron sin dudar- lo la modernidad -agua corriente, calefacción, bombillas, teléfonos, radios, máquinas de coser, etc.-, cultivando así cierto sibaritismo que les diferenciara de las clases medias y bajas.

La llegada de la electricidad a las calles y, en menor medida a los hogares, conseguirá liberar al mundo urbano de las tinieblas, como afirma Otero Carvajal2 ${ }^{21} ; \mathrm{y}$, junto con los nuevos medios de transporte público -tranvías, ómnibus y, ya posteriormente, el metropolitano- y privados los automóviles particulares, que llegan a Madrid ya con el nuevo siglo XX- no sólo cambiarán la fisonomía de los espacios urbanos, sino que modificarán hábitos y costumbres, facilitando la vida cotidiana.

La prosperidad alcanza poco a poco a ciertos sectores de las clases medias urbanas, permitiéndoles dedicar más tiempo al ocio, que dedican a alternar en casinos, ateneos, teatros y cafés con el anhelo de entrar en el "exclusivo" círculo burgués, rompiendo los límites de clase. Las distintas clases sociales intentan "progresar", como explica Castro y Serrano - “El que nació para vendedor ambulante, quiere ser tendero; el que nació para tendero, quiere ser comerciante; el que nació para comerciante quiere ser banquero; el que nació para banquero, quiere ser príncipe: todos llevan los frenos trocados" ${ }^{22}$, en un texto que juzga negativamente el humano deseo de prosperar. Las clases medias aspiran acceder al espacio social de los nuevos ricos para hacer negocios o casar a las hijas con un "buen partido", como reconoce doña Restituta en El teatro Moderno (1870), confesando a su hija: "Yo por ti me sacrifico / siempre de aquí para allá, / a la Castellana, al Prado, / al Paraíso del Real, / a los cafés... iqué sé yo!"23. Triunfa el arte de aparentar, las gentes acuden al teatro gastando 20, 30 o 450 reales en un asiento porque todo el mundo lo hace, porque es donde hay que estar para ser alguien en aquella sociedad urbana.

En cuanto a los sectores superiores del segmento obrero -no la gran mayoría que sufría por sobrevivir ${ }^{24}$, sino los pocos que lograban vivir en tal contexto-, también anhelaban "asaltar" los espacios burgueses, tratando, en la medida de sus posibilidades, de imitar los usos y costumbres de las clases "pudientes" 25 . Sin embargo, el sistema de especialización del trabajo que imponía 
aquella sociedad en trance de industrialización, regalaba a los acomodados tiempo y dinero para los ocios de la ciudad, bienes inalcanzables para las clases trabajadoras coetáneas.

Este juego de jerárquica mímesis es retratado paródicamente en el sainete de costumbres LoS enemigos domésticos (1867) de Picón y Arrieta, estrenado por la compañía de los bufos en el Teatro del Circo. En la obra, los criados, perfectos informantes para los de su clase de los comportamientos burgueses à la page, abusan de sus amos al conocer sus muchos vicios, llegando, al final de la obra, a celebrar su propia fiesta de criados en el salón de los amos. La apropiación del espacio y el papel social de los señores de la casa son subrayados, además, por el uso del tema melódico del festín de Lucrezia Borgia, ópera de Donizetti que esos mismos días se estaba interpretando en el Teatro Real de Madrid. La obra produjo no poca controversia por el tema escogido, sintiéndose atacado el público burgués del Circo $^{26}$.

Al igual que la antigua nobleza durante los años treinta, la burguesía organizaba reuniones privadas, soirées y tertulias en sus salones, manteniendo, incluso, el día "de recibir", en el que es posible frecuentar a la familia. Como recoge Castro y Serrano en 1862, la señorita casadera

sabrá cantar, tocar el piano, nadar, montar a caballo, pintar al fresco, tirar a pistola, hablar mejor que el suyo cualquier idioma extraño [...] tendrá además la costumbre de concurrir dos veces por semana al teatro, otras dos a tertulias de confianza, una á suarés (vamos españolizando la palabra) de gran tono, y otra recibirá en su propia casa, sirviendo el té a los amigos de su padre ${ }^{27}$.

En esas reuniones de sociedad, la música siempre estaba presente, funcionando como un "adorno" de distinción cantar o tocar el piano -sobre todo, entre las señoritas- en reuniones donde triunfa el dilettantismo. Ya Arrieta, en la zarzuela bufa Un sarao y una soirée (1866), ridiculiza la wagneriana "música del porvenir" 28 que consigue aburrir hasta el sueño a los presentes de aquellas reuniones con música, cenas en forma de buffet y, a partir de la década de los sesenta, también bailes como revela la sátira La Can-canomania (1869) de Enrique Gaspar.
La aristocracia y la alta burguesía -altos funcionarios del estado, políticos y militares- se reunían, además, en banquetes y bailes celebrados en sus grandes hoteles, conciertos y fiestas diversas, apartados del resto de la sociedad. En estos casos, la mezcla es evitada con la exclusividad del espacio privado, privilegiando así su endogamia.

La prensa se hace eco primero con la palabra, y posteriormente con la imagen, de prácticas de sociabilidad procedentes casi del Antiguo Régimen que, además, revelan pocas variaciones a lo largo de esta segunda mitad del siglo. Quizá el elemento más curioso, como ya hemos citado, es la incorporación del baile, práctica que produce verdadero furor a partir de los años sesenta del siglo XIX, que se mantiene en las reuniones de sociedad hasta la I Guerra Mundial, como manifiestan las numerosas publicaciones que dan buena cuenta de ello 29 .

\section{Sociedades, teatros y música en el Madrid de mediados del siglo XIX}

La aristocracia, con la Reina a la cabeza, y alta burguesía adoran la ópera italiana que se escucha en Madrid en el teatro del Circo hasta 1850 y en el Real a partir de su apertura ese mismo año. El resto de población no tiene fácil hacerse con un abono o una entrada en el Real, pero escucha la ópera de mil y una maneras: en el piano del café, en las orquestinas de las sociedades recreativas o instructo-recreativas, en las danzas de las sociedades de baile, en las bandas de música que empiezan a poblar los quioscos de los nuevos parques públicos, en el circo ${ }^{30}$ e incluso en el organillo callejero, "Persianis en miniatura, escrúpulos de Ronconi" ${ }^{31}$ que recorren las calles de la capital.

La música suena también en los salones de Palacio, las mansiones de la aristocracia y las tertulias de las residencias burguesas, donde se leen poesías, se juega a las cartas y algunos aficionados hacen música, sobre todo, fragmentos de ópera italiana y canción española ${ }^{32}$. Como ha estudiado Alonso, los salones de mediados de siglo mantenían una habitual convivencia de repertorio extranjero y música nacional, sobre todo canciones españolas de Iradier, Soriano, Manuel Sanz, Oudrid. Muchas familias hacen música en casa a la guitarra o al piano, frecuentemente con 
auxilio de la voz, como recogen las fuentes coetáneas:

el piano ha sido siempre el instrumento favorito de los compositores y de toda clase de aficionados a música, asi como ha llegado a ser hoy el mueble indispensable en todas las casas, y particularmente en las moradas o quintas de recreo, donde se vive apartado de los grandes centros y de las grandes ciudades ${ }^{33}$.

El asociacionismo es otro de los fenómenos clave para el desarrollo del ocio musical en la España de mediados del siglo XIX. Aunque algunas sociedades de la década de los cuarenta se vean afectadas por el Decreto Orgánico de Teatros de 1849 -ya que la ley les impone una carga fiscal si ofrecen funciones teatrales-, las estadísticas siguen manifestando la pujanza del movimiento asociativo en el caso de las asociaciones profesionales, filarmónicas -Liceos, Ateneos o Institutos-, corales, mutuales y de baile ${ }^{34}$. De hecho, en buena medida, el desarrollo de la zarzuela y el cultivo de la música sinfónica a través de la primera orquesta estable que se crea en nuestro país dependen de dos asociaciones profesionales, en las cuales estuvo implicado Francisco Asenjo Barbieri: la Sociedad Lírico Española y la Sociedad de Conciertos de Madrid.

La primera, la Sociedad Lírico Española, es una sociedad de artistas -Barbieri, Gaztambide, Oudrid, Hernando e Inzenga, compositores; Olona, escritor; y Salas, cantante lírico- que se crea con la intención de explotar mercantilmente el género lírico en el teatro del Circo-Olímpico justo en el momento en que este teatro se ve desocupado tras haberse inaugurado el Teatro Real en octubre de 1850. El éxito conseguido con la zarzuela grande les anima, cinco años después, a comprar un solar en la calle de Jovellanos y construir un teatro propio, el de la Zarzuela, coliseo que se inaugura en octubre de $1856^{35}$. El repertorio de zarzuela que se estrena en estos años, alimentado en lo literario por el mundo francés y en lo musical por las evanescencias y formas estructurales del belcanto italiano, no es un género popular todavía, es el género de la burguesía que ha triunfado en el nuevo régimen isabelino: los autores y compositores que lo cultivan proceden de las clases medias profesionales que se han hecho a sí mismos y logran triunfar en estos años, y el público que llena los tres teatros existentes principales de la década de los cincuenta -Circo, Real y Zarzuela- es un público eminentemente burgués, al que se suma la nobleza y la corte.

Estos tres teatros son coliseos construidos "a la italiana", con un espacio jerarquizado en pisos y dividido en palcos propio de los teatros del Antiguo Régimen; sin embargo, tras asumir la costumbre francesa del entreacto ${ }^{36}$, durante el cual los caballeros llevan a cabo el "visiteo de palcos" ${ }^{37}$, se pasean por los salones de descanso, suben y bajan escaleras, visitan el café y los salones de juego o de fumar, charlan, se mezclan y conviven como nunca antes. Estas costumbres se mantienen idénticas en la segunda mitad del siglo, llegando a exclamar algunos abonados ya en 1900:

A nosotros nos gustaría una función de ópera compuesta sólo de entreactos. Los entreactos son la delicia de las 'águilas' del Real, pájaros de [...] poco dinero que penetran en el teatro sólo con la entrada, aunque muy vestidos de frac; suben al paraíso, que es como cernerse en las alturas, desde el cual escrutan los palcos ocupados por familias amigas, buscando entre aquéllos algunos donde no sean muy numerosos los ocupantes $y$, majestuosamente descienden a posarse en el lugar elegido para presenciar sin causar molestia, muy pegaditos al fondo del palco, todo el acto aque ${ }^{38}$.

El Circo y la Zarzuela están ubicados en una zona en expansión en estos momentos, el Circo, en la Plaza del Rey, colindante con la calle BarquiIlo -justo al lado de la casa donde vive Barbieri-, y el de la Zarzuela, en la calle de Jovellanos, en un solar comprado por los autores que levantan el edificio entre marzo y octubre. Ambos están próximos al eje Prado-Recoletos-Castellana, zona de recreo coetánea.

El del Circo, una especie de barracón donde había ofrecido funciones circenses desde 1842 el francés Paul Laribeau ${ }^{39}$, tras ser comprado por José de Salamanca, se había convertido en el teatro de la ópera italiana entre 1843 y 1848, albergando una de las mejores compañías de ópera de Europa $^{40}$. Salamanca remodela el antiguo espacio, construyendo un teatro moderno, de 2076 butacas, con ventilación y calefacción incluidas, que es bendecido con la asistencia de la Reina y alguno de sus ministros, a los que acompaña 


\begin{tabular}{|l|c|}
\hline \multicolumn{1}{|c|}{$\begin{array}{c}\text { Temporada 1856/57 } \\
\text { Precio de cada localidad por noehe] }\end{array}$} & $\begin{array}{c}\text { PREC10 } \\
\text { (reales) }\end{array}$ \\
\hline Palcos principales sin entrada & 30 \\
\hline Palcos segundos de proscenio sin entrada & 30 \\
\hline Palcos segundos sin entrada & 25 \\
\hline Butacas con entrada & 12 \\
\hline Delantera de galeria de platea con entrada & 7 \\
\hline Asientos de galeria de platea con entrada & 5 \\
\hline Delanteras de anfiteatro entresuelo con entrada & 8 \\
\hline Asientos de anfiteatro entresuelo con entrada & 6 \\
\hline Delanteras de anfiteatro principal con entrada & 7 \\
\hline Asientos de anfiteatro principal con entrada & 4 \\
\hline Delantera de galeria con entrada & 5 \\
\hline
\end{tabular}

Fig. 1. Precios del Teatro de la Zarzuela para la temporada inaugural (1856-57). Fuente: Diario Oficial de Avisos, Madrid, 19-9-1856, p. 4

la aristocracia cortesana y la alta burguesía, con los que Salamanca hace grandes negocios que le otorgan pingües beneficios.

El Teatro de la Zarzuela es producto de artistas profesionales que invierten su dinero en la construcción de un teatro para explotar la zarzuela grande, a partir de 1851, nuevo género burgués de moda, un género, por sus exigencias musicales, asimilable a la ópera del primer romanticismo italiano o a la opéra-comique, que la burguesía coetánea devora con fruición noche tras noche. Se trata de un teatro funcional, bien decorado pero no lujoso, que cuida los espacios sociales y la seguridad en caso de incendio - "hay suficiente número de escaleras para la cómoda circulación y la salida rápida del público en un momento crítico; hay un buen salón de descanso y un cómodo café"-, así como la parte técnica del escenario -"el escenario es muy capaz y el telar y juegos de bastidores están conformes a los adelantos actuales" ${ }^{41}$-. Además, el teatro, con un aforo de 1530 asientos, está diseñado con clara mentalidad mercantil, aumentando el número de buenas entradas baratas - "cómodos anfiteatros frente al escenario" 42 - para conseguir un negocio rentable y "hacer popular el estrenado coliseo"43, aunque convendría matizar qué significa exactamente "popular" en 1856. Los precios diarios del teatro revelan la existencia de muchas entradas baratas de 7, 5, 6 y 4 reales (fig. 1).

Llama la atención la adenda de "con" o "sin" entrada que acompaña a las localidades, y es que los teatros ofrecían la posibilidad de comprar el acceso a una zona del coliseo sin localidad o asiento, existiendo, incluso, en algunos de ellos lo que se conocía como "entrada de paseo", que, como su nombre indica, permitía pasar la representación deambulando sin sitio fijo -este espacio aparece, por ejemplo, en el plano del Teatro del Circo de Paul (fig. 2) ${ }^{44}$ y se mantiene en el teatro Apolo durante toda su existencia (1873-1929), "detrás de la galería del paraíso y separado de él por una barandilla de hierro" 45 . La zona de paseo será eliminada definitivamente por el Reglamento de Policía de Espectáculos de 1913.

El teatro de la Zarzuela inaugura un nuevo modelo productivo claramente burgués, al tratarse ya de una empresa que es propiedad de los gestores, que son los creadores y profesionales que escriben e interpretan el nuevo género zarzuelístico. Sin embargo, en el público que acude cada noche a aplaudir los estrenos de Barbieri, Gaztambide o Arrieta, pesa todavía la consideración del espectáculo como artículo social de consumo ${ }^{46}$. El teatro es una tribuna donde ver y dejarse ver, por ello, las funciones se celebran a luz plena -uno de los primeros ejemplos de oscurecimiento de la sala aparece en octubre de 1888, durante una representación de Lohengrin en el Real con Gayarre ${ }^{47}$-, manifestándose diversas quejas cuando la luz es muy baja, ya que eso no permite distinguir "desde los palcos a las personas que se hallan sentadas en el patio y [...] las jóvenes no pueden lucir sus trajes" ${ }^{48}$. Y es que, en la década de los setenta, el empeño de ostentación de riqueza había impuesto la práctica de "el día de moda", función que tiene lugar determinado día de la semana -lunes y viernes en el teatro de la Comedia, jueves en Apolo y Zarzuela, etc.- en el que es preceptivo vestir de gala. Curiosamente, cuando ya a finales de siglo miembros de la high life deseen asistir a la "cuarta de Apolo", tras salir de la ópera del Real vestidos de etiqueta, recurrirán a la creación del sistema contrario: la segregación de los "elegantes" en palcos privados, constituidos en lo que se denominó "sociedades de palco", sociedades exclusivas a las que sólo se puede ingresar tras la defunción de un socio. La primera de ellas tenía cinco palcos -Real, Comedia, Princesa, Apolo y Eslava ${ }^{49}$.

A pesar de este interés por la exhibición que se practicaba en los coliseos madrileños de las décadas de los cincuenta y sesenta, aquellos tea- 


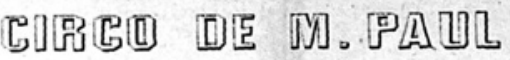

(Barquillo 7.)

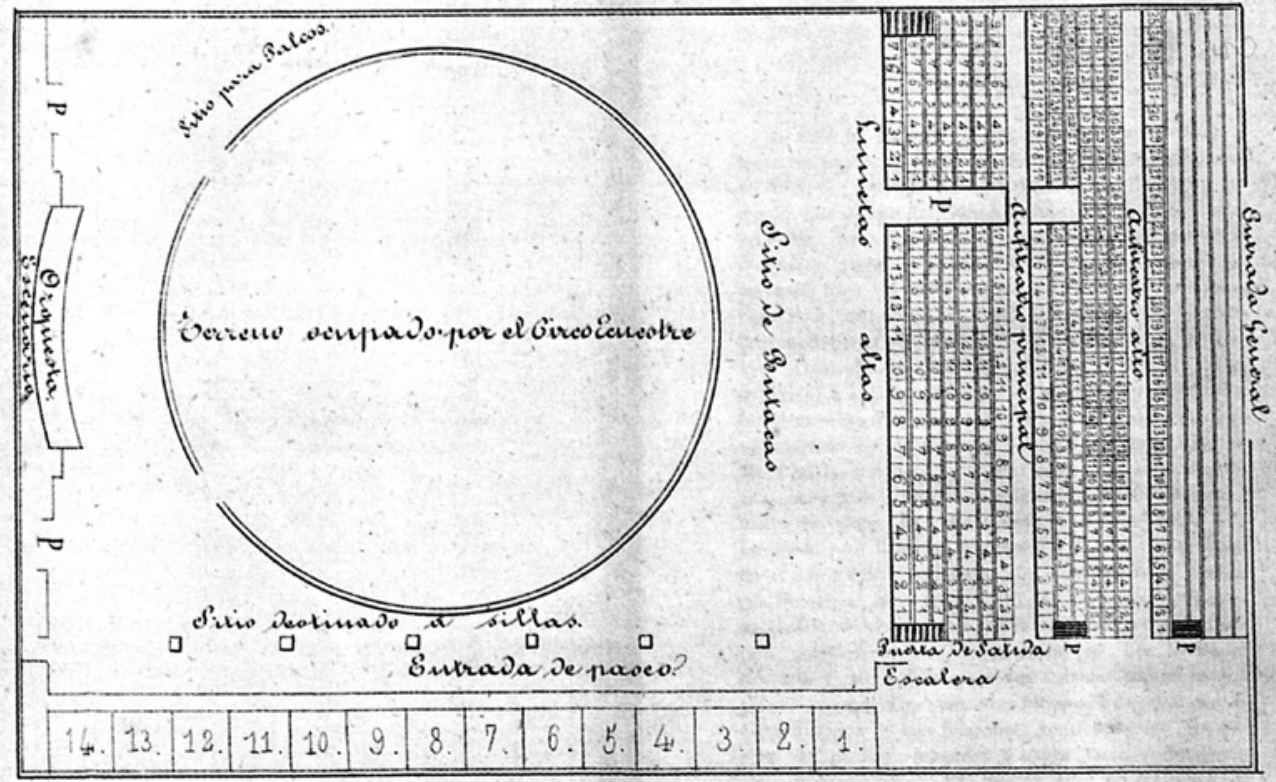

Fig. 2. Plano del Circo de M. Paul Laribeau hacia 1851

tros eran sucios e incómodos, en parte por el uso de sistemas de iluminación de aceite o gas, que manchaban habitualmente con polvo y aceite los vestidos de las damas, según recogen Fernández de Córdova en 1886 y Sepúlveda en 188850; estas circunstancias mejorarían notablemente tras la imposición por ley de iluminación eléctrica en los teatros a partir de $1887^{51}$, con el fin de evitar los frecuentes de incendios.

\section{Precios y públicos del teatro lírico: la ca- restía de un espectáculo burgués}

Los madrileños con capacidad adquisitiva asistían al teatro todas las noches, generalmente a través de un abono -que ofrecía interesantes descuentos de entre el 20 y $30 \%$ respecto a las entradas sueltas-, aun a costa de ver repetidas veces el mismo espectáculo musical o teatral.

No hay persona medianamente acomodada que no se crea en el deber de tener uno [abono] en el de la Zarzuela, a riesgo de caer en el ridículo más completo: se ha juzgado de buen tono la asistencia diaria y se sacrifican en aras de él la paciencia y la salud, escuchando cien noches seguidas Los magyares, Por seguir a una mujer y El magnetismo... animal! ${ }^{52}$.

Como ya hemos comentado, al teatro no se acudía a ver el espectáculo, sino a alternar; "las tertulias [...] se celebran ahora en los palcos de los veinte [teatros] que dan función diaria durante el invierno y en los jardines públicos de verano" ${ }^{53}$, confirma Fernández de los Ríos.

El aumento en la oferta tanto de localidades como de funciones lleva a algunos autores a asumir que en estos años sesenta se produce un proceso de ampliación de público que compromete a las clases populares, quienes supuestamente asistirían a las funciones teatrales con la misma asiduidad que el público burgués.

Villa Mínguez revela que, en 1862, el jornal diario de un trabajador era de ocho reales, lo que alcanzaba entonces para 1,86 dietas diarias ${ }^{54}$, es 
decir, no llegaba a sufragar los gastos de manutención de dos personas, cuando menos de una familia, jornal que impedía, a su vez, correr con el resto de los gastos vitales de una unidad familiar. Un ama de cría, por ejemplo, podría llegar a cobrar, según se anuncia en prensa ese mismo año 1862, 160 reales al mes, es decir, podría disponer de unos 5 reales diarios ${ }^{55}$. Si a esto añadimos la disponibilidad de tiempo libre para dedicar al ocio, y las necesidades sociales añadidas al hecho de "alternar" en el teatro -vestuario, desplazamiento, gasto de café, guardarropa...- la distancia se hace insalvable, resultando del todo punto imposible que un jornalero madrileño pudiera acudir a ninguno de los teatros existentes en Madrid en el primer lustro de la década de 1860.

Las clases medias acuden al teatro, pero dicha actividad compromete notablemente sus ingresos en aquel Madrid de la década de los sesenta. Castro y Serrano ofrece datos de primera mano en 1862, tratando de reconstruir la economía de un matrimonio recién casado de unos treinta y cinco mil reales de renta al año. La vivienda, muy cara ya entonces, suponía casi la mitad de dicha renta, pudiendo costar un pisito pequeño entre doce y catorce mil reales anuales -unos mil reales al mes. La necesidad de "alternar" y de aparentar ciertos lujos comprometía de continuo la economía familiar, desde la carestía de la ropa - " idiez duros un chaleco!, jdoce un pantalón!, jtreinta y cinco un frac!, icincuenta un paletot" ${ }^{\prime 56}$; hasta las costumbres de malcomer en una fonda -dos duros- o participar de una tertulia nocturna, donde jugar una onza -trescientos veinte reales ${ }^{57}$ - en una partida d'écarté era habitual.

Asistir al teatro Real era obligado pero altamente gravoso ya que suponía, además, una serie de gastos asociados de forma viciosa: la visita al café antes de acudir al teatro -un quesito helado para la dama y un café para el caballero-, 4 reales, a los que hay que sumar el coche alquilado previamente para ir de casa al café, 11 reales más; después, las entradas; evitando el palco, dos butacas que no sean ni delantera, ni última fila, podrían comprarse a uno de los muchos revendedores que pueblan la calle entre la Puerta del Sol y la Plaza de Isabel II, por unos 24 reales cada una, es decir, 48 reales la pareja. Una vez dentro, una banqueta para elevarse y poder ver desde la butaca para la dama, 4 reales; y los gemelos, olvidados en casa, 2 reales más. En el primer intermedio, un ramillete de flores para la dama -inada menos que 2 pesetas!, es decir, 8 reales-, y en el segundo, agua y unos dulces, 3 reales más. A todo esto hay que sumar el carruaje de regreso a casa, otros 14 reales. Es decir, que a una pareja, una noche modesta-sin champán, ni cena previa o fiesta posterior en Fornos-, le supondría un total de 94 reales $^{58}$.

Para tener un abono en el real, era necesario tener una renta alta -ocho o diez mil duros de renta anual- ya que en 1862, el abono diario de Pascua del Teatro Real puede llegar a costar 2135 reales, y entre 525 y 40 reales, el abono por turnos, que reduce notablemente el número de funciones. Un precio menor era el requerido para acudir a los teatros del Circo, en esa temporada en manos de Arrieta, que ofrecía un abono por 50 representaciones ${ }^{59}$, y del Príncipe, que ofrecía un abono por treinta, con precios que oscilan entre 70 reales por un palco de platea, 6 por una entrada en delantera de paraíso y 3 por una entrada general.

A pesar de estos precios, los madrileños llenaban todas las noches las diferentes salas teatrales de Madrid, para lo cual los teatros desplegaban diferentes estrategias de marketing y se reinventaban continuamente, tratando de ofrecer ofertas que les permitiesen fidelizar cada vez a mayor número de personas. En el año cómico 1869-70, cuarta campaña de la temporada de los bufos, la compañía, que se ha trasladado de un teatro pequeño, el Variedades, al teatro del Circo de la Plaza del Rey, ofrece un abono especial para señoras con butacas a 3 reales darios; es decir, acudir a ver 210 representaciones cuesta 630 reales $^{60}$. Además, dichas butacas, reservadas únicamente para las damas, estarán libres del "olor a tabaco que tanto las incomoda"61. Arderius garantizaba así, no sólo la asistencia de las damas, sino también la de caballeros -esposos o no- que acudirían en pos del "bello sexo" (fig. 3).

Ante estos pocos datos, resulta evidente que el teatro en general y el lírico en particular, a mediados de siglo resultaba "inasequible como forma de ocio regular para la población trabajadora asalariada"62. Castro añade a esta constatación que la situación cambiaría con el arraigo 

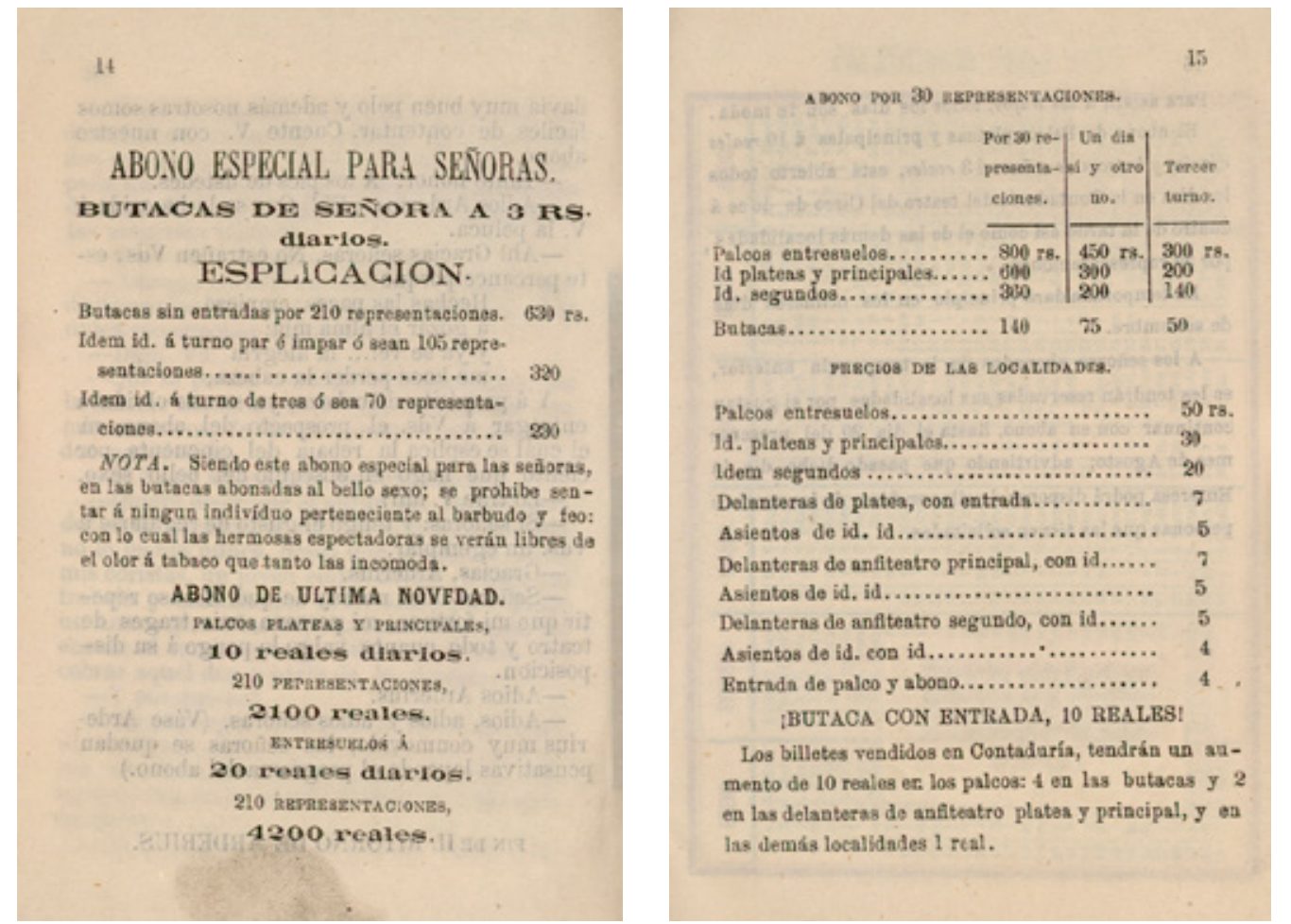

Fig. 3 a y b. Abono especial para señoras en los Bufos, Temporada 1869-70

del teatro por horas y el género chico durante la Restauración, sin embargo, el verdadero cambio llegó antes de manos de los café-teatros.

\section{El asalto a los café-cantantes}

Los Anuarios estadísticos de España publicados entre 1859 y $1867^{63}$ confirman un aumento significativo en el número de teatros de Madrid en este periodo -de ocho en 1861 a once en 1867-, el número de localidades disponibles -de 9815 en 1861 a 15501 en 1867- y el número de funciones por año cómico -de 1190 en 1861 a 1370 en $1867^{64}$. Esta ampliación en la oferta del número de espectáculos, en clara tendencia ascendente a medida que nos acercamos al final del siglo, confirma la capitalidad de Madrid en cuanto a actividad teatral, "casi la cuarta parte de la oferta nacional"65 (fig. 4).

Pero si cotejamos estos datos con los que arroja el Anuario administrativo del $1868^{66}$, es fácil comprobar que frente al aumento de cinco tea- tros de verso -Quevedo, Buenavista, Garcilaso, Fénix y de la Bolsa ${ }^{67}$ - que se añaden a los existentes en 1862, lo que crece de forma significativa son los café-teatros, que llegan a quince el año de la Gloriosa ${ }^{68}$. Como comentan Agulló y Cobo y Mejías, son teatros en los que el precio de una consumición -un real o real y medio- permite ver una pieza corta o un acto de una pieza grande, inaugurando ya la fórmula del teatro por secciones que vino a llamarse "género chico":

En estos lugares, consagrados a fortalecer el cuerpo y el alma, las funciones se dividen en tomas. Entra usted en el café y pide; en seguida le traen a usted el servicio y un billete. Apura usted su vaso de café y entra a ocupar su asiento. Acabado el primer acto, o se marcha usted a la calle o vuelve a tomar si quiere ver el segundo. La afición al verso va acompañada del amor a los licores. Con tres copas de ron, por ejemplo, puede usted ver tres actos. Si no lleva usted más que para una copa, se queda sin saber el desenlace del drama. [...] En resumen: se ha gastado usted seis $u$ ocho reales [...] podía 


\begin{tabular}{|c|l|c|c|c|c|}
\hline & TEATROS & AFORO & PROPIEDAD & DEDICACIÓN & CATEGORÍA \\
\hline 1 & Real & 2052 & Estatal & Lírico & $1^{\text {er }}$ orden \\
\hline 2 & Zarzuela & 1900 & Particular & Lírico & $1^{\text {er }}$ orden \\
\hline 3 & Circo & 1800 & Particular & Lírico & $1^{\text {er }}$ orden \\
\hline 4 & Príncipe & 1000 & Vecinal & Dramático & $1^{\text {er }}$ orden \\
\hline 5 & Novedades & 1500 & Particular & Dramático & $2^{\circ}$ orden \\
\hline 6 & Variedades & 813 & Particular & Dramático & $2^{\circ}$ orden \\
\hline 7 & Lope de Vega & 450 & Particular & Dramático & $3^{\text {er }}$ orden \\
\hline 8 & Buenavista & 300 & Particular & Varia & $3^{\text {er }}$ orden \\
\hline 9 & De Price & 2600 & Particular & Ejerc. ecuestres & $1^{\text {er }}$ orden \\
\hline
\end{tabular}

Fig. 4. Tabla de teatros en Madrid, en 1862. Elaboración propia. Archivo Histórico Nacional. Consejos. Leg. 11.405, nºs 108 a 160

haber ido a un teatro como el del Príncipe, donde le hubieran dado drama, baile y sainete ${ }^{69}$.

Pronto, algunos de estos espacios -El Recreo, De Marsella, De la Amistad o La industria- ofrecen títulos del repertorio zarzuelístico sin apenas gastos de producción, en competencia desleal a las empresas teatrales pero a favor de las clases más desfavorecidas que, "por el aliciente de la baratura"70, a un real la pieza, se convierte también en consumidor de teatro. El café es un espacio más asequible y accesible para las clases populares matritenses que cuenta con otro aliciente a su favor: el hecho de liberar a los trabajadores de "faire la toilette" y vestir lujosamente a la moda, detalles que sí imponían los teatros ${ }^{71}$.

Pronto -septiembre de 1867- los autores líricos cursan una denuncia por competencia desleal al Gobernador de Madrid, denunciando que en los cafés "no sólo se interpretan números sueltos, como romanzas o dúos, sino funciones completas al precio de un café"72, sin pagar por ello. La Reina dicta a favor de los autores prohibiendo la ejecución de obras completas, "pudiendo sólo interpretarse piezas sueltas interpretadas por el pianista y uno o más cantantes" ${ }^{\prime 73}$. Sin embargo, la realidad evidencia que los cafés-cantantes tuvieron larga vida, albergando un teatro sencillo, barato, por secciones, sin duda origen del teatro por horas que triunfará en la Restauración. No obstante, es ilustrativo observar cómo los sucesivos reglamentos de hacienda presentan siempre resquicios para que los cafés puedan salvar el impuesto de teatros, siempre y cuando no cobren cuota por "las diversiones o espectáculos que se den en el mismo local en que se sirva el café y demás bebidas, [...] no se exija precio de entrada o se recarguen con este objeto los de aquellos artículos" -recordemos que se cobra por la consumición y no por el espectáculo- o no tengan "local separado para funciones de declamación, canto o baile"74. Ante estas apreciaciones, cobra pleno sentido el cartel de anuncio de la función del domingo 29 de junio de 1873 en Capellanes, que proclama: "A todo concurrente a este CaféTeatro que haga consumo por valor de REAL Y MEDIO en adelante, se le regalará un billete para ver una de las funciones con su final de baile".

\section{Música y jardines de recreo en el Madrid de los sesenta}

El gusto de los madrileños por disfrutar de las noches de estío al aire libre cultivado en estos numerosos bailes campestres, propicia la aparición en 1864 del espacio de recreo más importante del Madrid de la segunda mitad del siglo XIX, los Campos Elíseos, área recreativa que se extendía en un terreno formado por las actuales calles de Alcalá, Velázquez, Goya y Castelló. El proyecto, propuesto al Ayuntamiento en 1861 por el empresario catalán José de Casadesús ${ }^{75}$ con el fin de dotar a la capital de un espacio similar al que ya tenía Barcelona desde 1853, se convirtió en el jardín de moda en la España isabelina, materializándose en "amplios y refinados jardines geométricos y paisajistas, bellas plazas adornas con quioscos, paseos arbolados y hermosos edificios"76, entre ellos, un coso taurino, una montaña rusa, el Teatro Rossini -de planta 

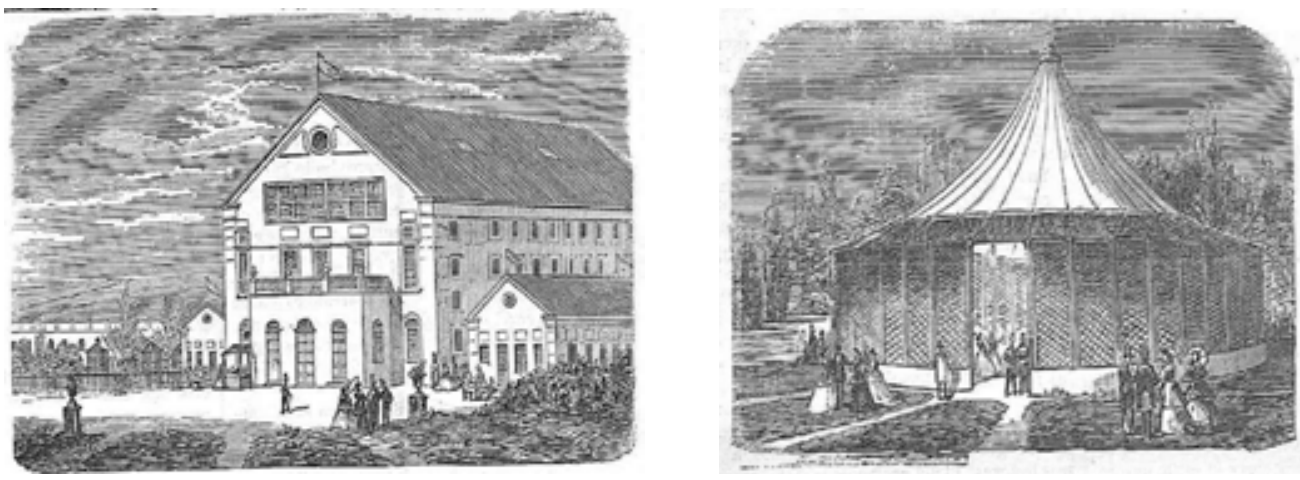

Fig. 5 a y b. Dibujos de Miranda, grabados por Ricod, del Teatro Rossini (izda.) y salón de música (dcha.). "Los Campos Elíseos". El Periódico llustrado, año I, n 12, 25-05-1865, 4

rectangular y cuatro pisos-, para dar conciertos, ópera, zarzuelas..., el salón de conciertos -“"caprichosa tienda de campaña"77 que puede contener hasta 2000 personas-, un local de tiro, una Casa de baños, una ría en la que disfrutar en elegantes barcazas e incluso un vapor llamado "Príncipe Alfonso"78, además de restaurantes, cafés, un ciclorama, un tío-vivo, pistas de patinaje, etc. El espacio de los jardines estaba iluminado con "diez mil faroles de papel y tela de diversos colores"79 (fig. 5).

Además de una excelente compañía lírica -en la que figuran, entre otros, el tenor Tamberlick, el barítono Aldighieri y el bajo Gassier-, coro y orquesta, dirigida por Barbieri -que también dirigía los conciertos orquestales-, el teatro de los Campos Elíseos contaba también con una compañía de baile ${ }^{80}$-solistas, más 28 bailarines y un grupo de niños; y la colaboración de la banda del quinto regimiento de infantería. La oferta musical del jardín era variada y simultánea, compitiendo los distintos espectáculos musicales entre sí, y con el resto de atracciones.

A las 5 de la mañana, apertura de los jardines. A las 6 de la tarde, fuegos artificiales y piezas de música por las bandas militares hasta las 10 de la noche. A las 9, función teatral. A las 9 y media hasta las 12 y media varias escogidas piezas de instrumental y canto en el salón de concierto. Éste, la plaza del teatro y los jardines estarán iluminados a la veneciana, oriental y chinesca ${ }^{81}$.

Los conciertos orquestales comienzan ya en el mes de junio de 1864, y será el 2 de julio cuan- do se inicie la exitosa campaña lírica del Teatro Rossini, con grandes beneficios económicos ${ }^{82}$. Tras la inauguración con la última ópera del compositor italiano, Guillermo Tell, se ofrecieron funciones durante ochenta días, interpretándose, además de esta grand opéra, Anna Bolena, las dos "nuevas para la generación presente y Faust, enteramente desconocida" ${ }^{83}$, El trovador, Otello y Polliuto, la Cantata a Rossini de Arrieta ${ }^{84}$ y los ballets Giselle, Ivonette y Flore et Amour. El ciclo de dieciocho programas de conciertos sinfónicos ${ }^{85}$ también fue muy aplaudido ${ }^{86}$, haciendo entender a Barbieri la necesidad de convertir esta iniciativa en estable, que se materializará con la creación en 1866 de la Sociedad de Conciertos $^{87}$.

Al año siguiente, 1865, es Joaquín Gaztambide -al que se puede ver a la izquierda, batuta en mano, en la Fig. 6- quien dirige la compañía de ópera italiana de los Campos Elíseos, que ofrece nueve obras diferentes con un total de setenta y cuatro representaciones; en el salón de conciertos tiene lugar de nuevo un ciclo de veinte conciertos orquestales (fig. 6).

El teatro Rossini ofrecía bastantes butacas baratas a 2, 3 y 6 reales (fig. 7); pero a todas ellas hay que sumarles la entrada al parque y los precios del transporte, de uso imprescindible al tratarse de un espacio alejado del centro, como reconocía ya al día siguiente del estreno del teatro, El Museo Universal: "un espectáculo del cual se sale a las dos de la mañana, quedándole a uno todavía una legua que andar para llegar a su domicilio [... ] a esto hay que añadir que la diversión es cara: el más ínfimo asiento cuesta once reales: 


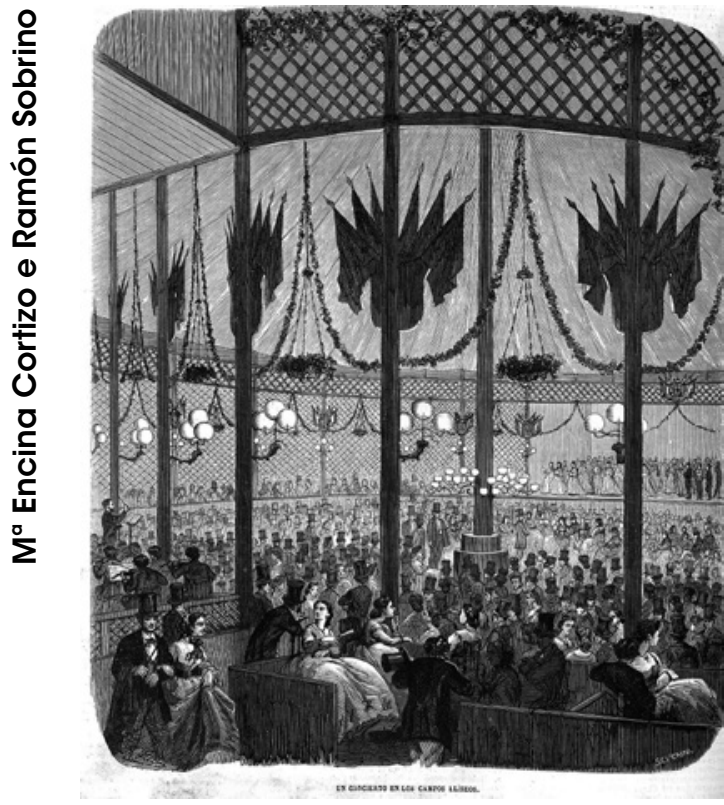

Fig. 6. Ilustración de Severini, "Un concierto en los Campos Elíseos". El Museo Universal, Año IX, n² 29, 16-07-1865, 4

tres la entrada, seis el asiento y dos los ómnibus indispensables" 88 .

Y es que, si bien el jardín público refleja el afán burgués por franquear el acceso a los nuevos espacios de ocio a públicos de menor nivel adquisitivo a cambio de una entrada barata de acceso $^{89}$, una vez dentro, nuevas entradas continúan limitando y segregando al público. Tanto el Teatro Rossini como los conciertos orquestales o los bailes de sociedad tenían un elevado precio y "requerían una estricta etiqueta en el vestido y el comportamiento con el fin de garantizar la exclusividad y el orden"90. En junio de 1865, la lluvia y el frío impone trasladar al interior del Teatro Rossini uno de los conciertos al aire libre; Galdós relata el "asalto" por parte del público popular a ese espacio vetado casi en términos revolucionarios.

aquella confusión de clases producida por la peseta niveladora, aquella democrática invasión que hace en las butacas el público de los conciertos a la intemperie, ocupándolas indistintamente con cierto desenfado republicano, es muy agradable; los acomodadores, incorruptibles guardianes de aquella propiedad, desaparecen para dar paso a las turbas,

\begin{tabular}{|l|c|}
\hline \multicolumn{2}{|c|}{$\begin{array}{c}\text { Temporada de verano, } \\
\text { Precios en Contaduria } \\
\text { Localidades }\end{array}$} \\
\hline $\begin{array}{l}\text { Precios } \\
\text { (reales) }\end{array}$ \\
\hline Palcos bajos y plateas sin entrada & 230 \\
\hline Butaca con entrada al teatro & 26 \\
\hline Delantera de palco con entrada & 10 \\
\hline Centro de palco & 6 \\
\hline Antepechos de paraiso & 6 \\
\hline Asiento de frente paraíso & 3 \\
\hline Entrada general & 2 \\
\hline
\end{tabular}

Fig. 7. Precios del Teatro Rossini de los Campos Elíseos. Verano de 1864

que corren a arrellanarse en los sitios, donde otros días la riqueza, entusiasta también de la música, se sitúa cómodamente para halagar con el canto de Tamberlick su oído metalizado. Fijando la atención, se notará en algunas caras de la alta clase más de un gesto avinagrado91.

Tras nuevas temporadas en las que mantienen los conciertos sinfónicos, la música de banda en el quiosco y el coso taurino, el espacio comienza una lenta decadencia, hasta que cierre sus puertas en 1870, para posteriormente ser demolido.

Al año siguiente, el empresario Felipe Ducazcal abrirá los Jardines del Buen Retiro que vienen a sustituir a los anteriores Campos Elíseos; este nuevo espacio de recreo será crucial en el Madrid de la Restauración, hasta su desaparición en $1905^{92}$.

\section{"¡Ay, qué gusto es bailar...!": las socieda- des de baile}

Uno de los ámbitos de ocio que encontramos en franco desarrollo en el Madrid de las décadas de 1850 y 1860 son las sociedades de baile, que se diversifican según su clase, repartiéndose los distintos espacios públicos -como el Eliseo madrileño que canta el chotis en la apoteosis de la revista La Gran Vía (1886)- y privados, abiertos y cerrados, para solaz de madrileños de toda clase y condición.

Al igual que sucede con el teatro, las numerosísimas sociedades de baile retratan de forma perfecta la estratificación social de la sociedad 


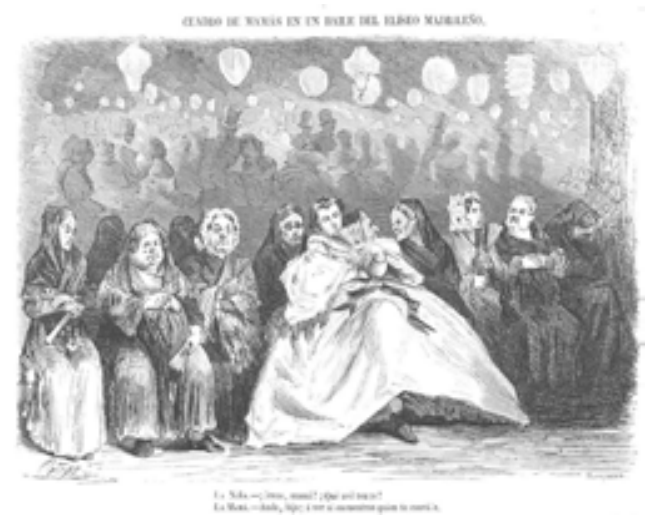

Fig. 8. Grabado de Ortego. El Museo Universal, año IV, $\mathrm{n}^{\circ} 33$, 12-08-1860, 8

burguesa: no es la sangre o el nacimiento sino el dinero el que segrega al público.

Ya entre 1848 y 1855 encontramos ya numerosísimas sociedades matritenses de baile como Terpsícore, la Juventud Española, la Oriental, el Buen tono, el Guante de oro, la Española, Apolo, el Judío Errante, la Ondina, la Sílfide, Marte, la Perla Madrileña, Minerva, la Floreciente, la Ceres, la Concordia, Talía, Juanita, la Juventud Vascongada, la Juventud Vasco-Madrileña, la Rosa, la Iberia, la Joven España, la Unión Francesa, el Pabellón Español, la Romana, el Carnaval, el Diamante, el Fénix, el Nuevo Liceo o la Camelia. Las más antiguas se situaban extramuros ${ }^{93}$, en espacios abiertos, campestres, próximos a alguna de las puertas de la ciudad que serán derribadas con el ensanche -la Juventud Vascongada, en el hipódromo; la Juventud española, extramuros de la Puerta de Alcalá; y la Sociedad Vascomadrileña, en el Ariel, "extramuros de la puerta de Recoletos"94. Sólo se celebraban durante la temporada de verano, entre las tres y las siete de la tarde. Y ya en noviembre de 1851, según afirma el gacetillero de La Ilustración, aquellas "sociedades de baile a escote y de amor a cielo raso crecen asombrosamente" ${ }^{95}$.

Poco a poco, algunas sociedades fueron instalándose intramuros, en bajos del centro de Madrid, para celebrar bailes primero en torno al Carnaval -en clara mímesis de los de Palacio y el Real-y posteriormente también en otoño y el resto del invierno. Las sociedades se juntan para hacer frente a los gastos de alquiler, buscando

\begin{tabular}{|c|c|}
\hline \multicolumn{2}{|c|}{ Bailes de Madrid, febrero de 1861 } \\
\hline \multicolumn{2}{|c|}{ Bailes públicos } \\
\hline De verano & De invierno \\
\hline El Eliseo madrileño & Capellanes \\
\hline Las Delicias & Circo de Paul \\
\hline El Ariel & Placeres de la Corte \\
\hline La Juventud española & La Simpática \\
\hline Vistillas & La Juventud artística \\
\hline Circo de Paul & Recreo de la juventud \\
\hline & Salones de BB. AA. \\
\hline & Crucero \\
\hline Bailes en las afueras & Bailes en los teatros \\
\hline Chamberí & Teatro Real \\
\hline Virgen del Puerto & Zarzuela \\
\hline San Antonio de la & Príncipe \\
\hline Florida & \\
\hline Pradera del Canal & Instituto \\
\hline Puente de Segovia & Lope de Vega \\
\hline Fuente de la Teja & \\
\hline Ventorrillos del & \\
\hline Manzanares & \\
\hline Ventorrillos del norte & \\
\hline
\end{tabular}

Fig. 9. Principales bailes de Madrid en febrero de 1861. Fuente: La Correspondencia de España, 15-2-1861, p. 3

salones para celebrar sus bailes dominicales. Es el caso de Marte y Terpsícore, la Perla Madrileña y la Aurora ${ }^{96}$ que en 1850 alquilan un salón en el número 8 de la Calle de la Madera. En 1851, cuando el Circo está estrenando Jugar con fuego, la sociedad denominada la Amistad Floreciente se abre al público en la calle Pizarro. Y ya en noviembre de 1853, la sociedad de la Romana encuentra asilo en los salones del Circo de Paul de la calle Barquillo, anunciando que cuenta con una numerosa orquesta ${ }^{97}$ para ofrecer bailes "todos los jueves, de ocho a doce y media de la noche" ${ }^{98}$.

El Teatro-Circo de Paul o "Pol" -transcripción fonética habitual ya en la década de los sesenta- se convirtió en un espacio emblemático para disfrutar del baile en Madrid en los cincuenta y los sesenta, acogiendo diferentes sociedades de baile -la Romana en 1853; la Constante y la Juventud española en 1859, con bailes cada sábado y domingo, de cuatro a siete de la tarde la primera, y de nueve a una de la madrugada, la segunda ${ }^{99}$. Sin duda ayudó a esta especialización el contar con una amplia estructura circular de pista de circo para bailar, inserta en una planta rectangular, con espacios para sentarse, ver y ser 


\begin{tabular}{|c|c|c|}
\hline AÑos & $\begin{array}{c}\text { SOCIEDADES DE } \\
\text { RECREO }\end{array}$ & TEATROS \\
\hline 1861 & 983 & 293 \\
\hline 1862 & 957 & 302 \\
\hline 1863 & 1078 & 299 \\
\hline 1864 & 1178 & 298 \\
\hline 1865 & 1225 & 296 \\
\hline 1866 & 1318 & 318 \\
\hline 1867 & 1353 & 335 \\
\hline
\end{tabular}

Fig. 10. Números totales de sociedades y teatros en España (1861-1867)

visto, pudiendo alcanzar un aforo de unas dos mil personas. Era un espacio tan imbricado en la vida urbana que en la primera revista lírica de nuestro país, 1864 y 1865, estrenada en el Circo en enero de 1865, Gutiérrez de Alba, en la habanera que canta la Danza en el número 2, escribe: "No me lleves a 'Pol' / que me verá Papa, / llévame a Capellanes / que estoy segura / que allí no va"100.

Al igual que el Circo de Paul, también el Salónteatro de Capellanes empezó ya en los cuarenta a acoger a diversas sociedades de baile como el Guante de oro, a la que se sumó el Liceo Matritense en el Carnaval de 1851 y el Pabellón Español al año siguiente, 1852. En 1854 Capellanes es ya el más importante salón matritense de baile, acogiendo nada menos que cuatro sociedades que ofrecen diversión en días alternos: el Casino matritense, los domingos; el Liceo amistoso, los martes; la Romana, los jueves, y el Carnaval, los sábados $^{101}$. La afición va en aumento, y otras sociedades como la Unión Dramática y el Instituto que han celebrado bailes de Carnaval en el Teatro de Lope de Vega, confirman ya en 1859 que continuarán en dicho coliseo, ofreciendo bailes sábados y domingos ${ }^{102}$.

Uno de los bailes campestres, el Eliseo madrileño ${ }^{103}$, que ofrece sesiones de baile jueves y domingos de verano en su jardín de Recoletos, donde "la música de las habaneras adormece o exalta los sentidos" a representantes del "comercio, las modas, la milicia y las artes más útiles de la sociedad"104, decide, en 1863, mantener los bailes también en invierno, instalándose para ello en el Circo de Paul, donde convoca a bailar los domingos de ocho y media a una de la noche ${ }^{105}$ (fig. 8).
En el año 1861 existen en Madrid 123 sociedades dramáticas, 139 sociedades de música, 145 sociedades de baile -intramuros, extramuros e incluso en ventorrillos de las afueras (fig. 9)- y 575 sociedades casinos, y la mayor parte de madrileños adultos estaba inscrita en una o varias de ellas ${ }^{106}$ (fig. 9).

De hecho, son las sociedades de recreo las instituciones de diversiones públicas que más crecen entre 1861 y $1867^{107}$, en mayor proporción que los teatros (fig. 10).

En 1862 contamos con cinco salones públicos dedicados al baile en Madrid (fig. 11) ${ }^{108}$ : el teatrocirco de Paul109, el Salón de Capellanes, el Elíseo madrileño -con cabida para 2000 personas en su sede veraniega de Recoletos-, Ariel, el Paraíso y el Liceo madrileño. Los cuatro últimos eran bailes de verano al aire libre, situados, los tres primeros, extramuros, el Eliseo ${ }^{110}$ en Recoletos; el Ariel, en el Paseo de la Castellana ${ }^{111}$; y el elegante baile del Paraíso, próximo a la antigua Puerta de Santa Bárbara ${ }^{112}$-hoy Alonso Martínez (fig. 11).

Las funciones veraniegas de todos ellos se componían de "baile, música, fuegos artificiales, cuadros disolventes o representaciones dramáticas" 113 , como revela el anuncio del baile del domingo 6 de julio de 1862 en el Eliseo madrileño:

Dos orquestas, con 130 profesores, a saber: la de Ingenieros de 80, y la del Elíseo de 50, tocarán alternativamente piezas notables y escogidas de las mejores óperas, zarzuelas y para baile. La de Ingenieros se situará al lado del teatro, cuyo salón lleno de asientos estará abierto al público e iluminado fantásticamente. Gran exposición extraordinaria de fuegos artificiales y combinaciones nuevas de lucería y chispería. Alumbrado general del local, a la veneciana ${ }^{114}$.

Los precios de los mismos (fig. 11) eran muy asequibles -entre 4 y 6 reales los caballeros ${ }^{115}-$, y 2 las señoras o "de convite", es decir, gratis, las más de las veces; solían celebrarse los domingos bien por la tarde -a las cuatro o las cinco- los campestres y hacia al anochecer -siete y ocho de la noche- los más céntricos, y estaban alimentados de criadas, horteras, artesanos y jornaleros con sueldo fijo, que "libraban" en sus quehaceres 


\begin{tabular}{|c|c|c|c|c|c|}
\hline BAILES & AFORO & UBICACIÓN & DEDICACIÓN & DLA Y HORA & Precio \\
\hline Teatro de Paul & 1200 & C/Barquillo, 7 & Baile & & $10 \mathrm{rs}$. \\
\hline Salón Capellanes & 800 & $\mathrm{C} /$ Capellanes, 10 & Baile & & $10 \mathrm{rs}$. \\
\hline Eliseo madrileño & 2000 & $\begin{array}{c}\text { Paseo Recoletos } \\
\text { [frente al palacio de } \\
\text { Salamanca] }\end{array}$ & Baile campestre & $\begin{array}{c}\mathrm{Ma} / \mathrm{J} \text { y } \mathrm{D} \text { de } 19 \\
\text { a } 24 \mathrm{~h} . \\
\text { y de } 20 \text { a } 2 \mathrm{~h} .\end{array}$ & $\begin{array}{l}\text { Cab: } 4 \text { ó } 6 \text { rs. } \\
\text { Señ. gratis }\end{array}$ \\
\hline Ariel & 300 & Po de la Castellana & $\begin{array}{l}\text { Baile campestre } \\
\text { [verano] }\end{array}$ & $\mathrm{D}, 16 \mathrm{~h}$ & \\
\hline El Paraíso & & Pta. Sta. Bárbara & $\begin{array}{l}\text { Baile campestre } \\
\text { [verano] }\end{array}$ & $\begin{array}{l}\text { J. } 20: 30 \text { a } 1 \mathrm{~h} . \\
\text { D, } 19 \text { a } 24 \mathrm{~h} .\end{array}$ & $\begin{array}{l}\text { Cab: } 6 \text { rs. } \\
\text { Señ. } 2 \text { rs/gratis }\end{array}$ \\
\hline Liceo madrileño & & $\begin{array}{c}\text { Prado, frente al } \\
\text { Botánico }\end{array}$ & $\begin{array}{l}\text { Baile } \\
\text { [verano] }\end{array}$ & $\begin{array}{c}\text { D, } 16 \text { a } 20 \mathrm{~h} . \\
17 \text { a } 21 \mathrm{~h} .\end{array}$ & \\
\hline
\end{tabular}

Fig. 11. Tabla de salones públicos de baile en Madrid, en 1862

esa tarde de la semana, tras dejar "arreglados" los menús y la casa de los amos ${ }^{116}$.

En Madrid tienen también larga tradición los bailes de máscaras de Carnaval, siendo los más concurridos los del Real y la Zarzuela -al precio de 24 reales el billete ${ }^{117}$. En 1862, la prensa, revela, incluso, el repertorio de danzas del primero de los cuatro bailes de máscaras de ese año en la Zarzuela, que tendrá lugar la víspera de Reyes, el 5 de enero: "tocará la orquesta con intermedios de diez minutos, dos veces vals, cuatro polka, dos chotis, dos habaneras y un gran galop"118 (fig. 12).

La diferencia social se observaba, en el caso de los bailes, en el repertorio y los medios manejados en cada caso. El Paraíso, por ejemplo (fig. 12) ${ }^{119}$, cuenta en el verano de 1862 con dos "orquestas" -bandas, en realidad- con ciento cuarenta profesores, y coro de miembros del coro del Teatro Real. Por 6 reales a los caballeros y tan solo 2 a las señoras, el domingo 15 de agosto, a las ocho de la tarde, ofrece un nutrido programa de baile, con algunas piezas de concierto (fig. 13) ${ }^{120}$.

En 1863, el Eliseo madrileño -en Recoletos durante el verano y en el Circo de Paul en inviernoy el Salón de Capellanes -que alberga ese año a la Novedad y la Floreciente ${ }^{121}$ - se mantienen como los más importantes espacios matritenses de baile para solaz de las clases trabajadoras ${ }^{122}$. Ya en 1865, Pérez Galdós dedica al Salón de Capellanes una de sus revistas semanales de La Nación, elogiando la rústica y desbocada felicidad de aquellos trabajadores que, lejos de la cursi afectación de la sociedad de buen tono, disfrutan del baile entre los trabajos y los días (fig. 14):

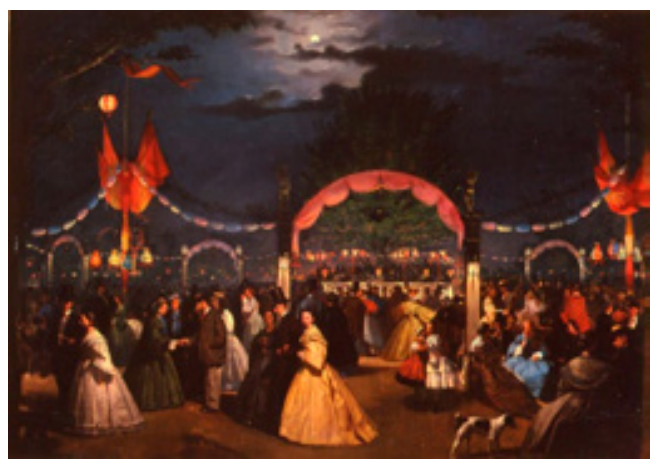

Fig. 12. El jardín público de Madrid llamado 'El Paraíso' en noche de baile (1862). Rafael Botella Coloma. Museo de Historia de Madrid

El baile de salón ha absorbido al baile nacional [...] Hoy el wals y la redowa se han apoderado de los pies de toda la humanidad [...] Las parejas se agitan sin descanso. La inercia pedestre de una semana de servicio doméstico da a sus extremidades una actividad portentosa. [...] iMirad con qué gallego candor se deja abrazar la fregatriz por el cochero, sin que un mal pensamiento cruce por su mente, a culinarias tareas dedicada! ¡Con cuánta inocencia reclina su cabeza groseramente peinada aquella espiritual niñera sobre el hombro de aquel lacayo del señorito! [...] Benditas mil veces vosotras, felices parejas, que al trocar la malagueña por el wals y el verde campo por el salón alfombrado, no habéis perdido vuestra encantadora sencillez ${ }^{123}$.

Thomas Price, para hacer más atractivos los espectáculos de su Teatro-Circo de la calle Recoletos, decide añadir un antiguo jardín anexo, en la calle del Cid. Pagando un suplemento de dos reales, se puede acceder al mismo en los en- 
Prácticas y espacios musicales de una ciudad burguesa en desarrollo

I parte
Gran sinfonía por la banda militar en la Glorieta.
Piezas de baile, con el coro -algunas de Iradier, alternando con las de concierto
Descanso,
en el que se quemará una brillante exposición de fuegos de artificio.
II parte
Gran sinfonía de la ópera Los mártires, por la banda, coros y órgano expresivo.
A la Patria, himno a voces solas, del director del Teatro Real, Juan Daniel Sckozdopole
Piezas de baile y concierto
Fin de fiesta
El Campamento, gran diana ejecutada por las dos bandas de música y dos de tambores y
cornetas "en la que se verá, por medio de bengalas la salida del sol"

Fig. 13. Programa del baile de El Paraíso, domingo 15 de agosto de 1862. Fuente: Diario Oficial de Avisos de Madrid, 14-8-1862, p. 4

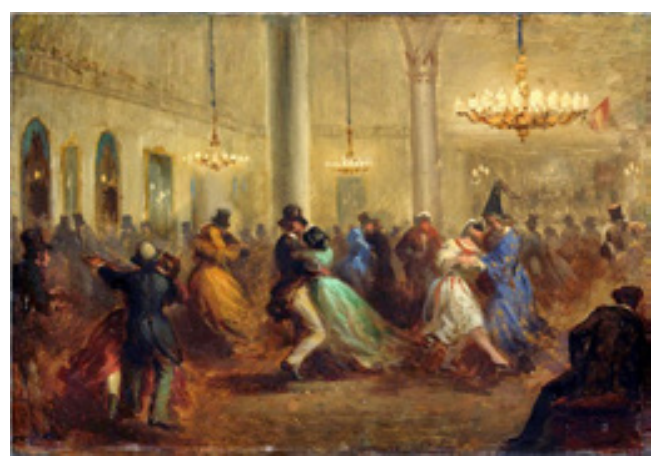

Fig. 14. El baile de Capellanes, por Ricardo Balaca, ca. 18601865. Museo de BB AA. de Bilbao

treactos, para degustar el buffet, a los sones de la orquesta; además, Price celebra en el jardín algunas verbenas, de nueve de la noche a tres de la madrugada ${ }^{124}$.

\section{Música instrumental en los años sesenta: de las sociedades a los jardines}

Las sociedades profesionales tienen también gran importancia en el ámbito de la música sinfónica. En 1862 se constituye la primera y efímera Sociedad Española de Conciertos en Madrid, promovida por la Sociedad Artístico-Musical de Socorros Mutuos, constituida, a su vez, en 1860. En 1863 Jesús de Monasterio y Juan María Guelbenzu crean la Sociedad de Cuartetos, activa hasta 1894. Los nuevos jardines de verano demandan actividad orquestal; así en el verano de 1864, en los Campos Elíseos actúa una orquesta dirigida por Barbieri; en el verano de 1865 compiten una orquesta con otra dirigida por Arban en el Príncipe Alfonso, y otra dirigida por Gaztambide en los Campos Elíseos; en 1866, ante la ausencia de conciertos en los Campos Elíseos, la Sociedad de Conciertos de Madrid actuará en el Jardín de Apolo de Recoletos; a partir de 1867 la Sociedad de Conciertos actuará habitualmente en verano en los Campos Elíseos.

La Sociedad de Conciertos, constituida en 1866 y activa hasta $1903^{125}$, desarrollará fundamentalmente dos temporadas: la de primavera, casi siempre en el Teatro del Príncipe Alfonso, uno de los de mayor capacidad de Madrid, y otra en jardines de verano -casi siempre en los Campos Elíseos, y en 1866 en los Jardines de Apolo-, donde solía ofrecer entre 20 y 35 conciertos, acercando el repertorio orquestal -más sencillo que el de las temporadas de primavera- a un público más amplio. En estas temporadas de primavera, los conciertos solían tener tres partes, interpretando en la segunda una sinfonía en cuatro movimientos o una obra de gran formato; en las temporadas de verano, los programas se organizaban sólo en dos partes. Estas orquestas favorecieron la creación de repertorio sinfónico español y dieron a conocer las grandes obras sinfónicas clásicorománticas $^{126}$.

El "Estado demostrativo de ingresos y gastos" de los conciertos ofrecidos por la Sociedad de Conciertos en el verano de 1866 -23 en el Jardín de Apolo del Circo Price, en el Paseo de Recoletos, y uno benéfico en los Campos Elíseos, entre 


\begin{tabular}{|l|c|c|}
\hline \multicolumn{2}{|c|}{$\begin{array}{c}\text { Conciertos de Primavera, 1868 } \\
\text { Circo del Príncipe Alfonso }\end{array}$} \\
\hline \multicolumn{1}{|c|}{$\begin{array}{c}\text { Precios de abono } \\
\text { cinco conciertos (en reales) }\end{array}$} & $\begin{array}{c}\text { Precio en } \\
\text { despacho } \\
\text { por concierto }\end{array}$ \\
\hline Un palco, sin entradas & 490 & 120 \\
\hline Butaca, con entrada & 80 & 20 \\
\hline Delantera de tribuna, con entrada & 50 & 12 \\
\hline Delantera de galeria, con id. & 40 & 6 \\
\hline Silla de tribuna, con id. & 25 & 6 \\
\hline Asiento de $5^{\mathrm{a}}$ fila de galería, con id. & 25 & 6 \\
\hline Id. de $1^{\mathrm{a}}, 2^{\mathrm{a}}, 3^{\mathrm{a}}$ o $4^{\mathrm{a}}$ fila de galería, con entrada & 20 & 5 \\
\hline Entrada general de palco y de paseo & & 4 \\
\hline
\end{tabular}

Fig. 15. Precios de los abonos para la campaña de primavera de la Sociedad de Conciertos (1868)

el 16 de julio y el 15 de septiembre ${ }^{127}-$, ofrece unos ingresos de 223.788 reales, que proporcionan a los profesores 135.612 reales. El precio del billete era de 4 reales. En los Jardines de Apolo se vendieron 55.572 billetes en 23 conciertos, oscilando entre los 4457 billetes del cuarto concierto, celebrado el 25 de julio, y los 1302 billetes del segundo, celebrado el 18 de julio, siendo la media de 2416 billetes por concierto ${ }^{128}$.

En junta general de enero de 1868, se fijaron los precios de los primeros abonos de la Sociedad de Conciertos para los conciertos de Primavera en el Circo del Príncipe Alfonso. Se abrió un abono para cinco conciertos, ofreciéndose después un concierto extraordinario (fig. 15).

Las actas de las Juntas de la Sociedad recogen el debate que tuvo lugar en 1872, en torno a la necesidad de subir los precios de las entradas de patio y butaca -10 y 4 reales respectivamente-, localidades ocupadas por las clases pudientes, dados los muchos gastos que tenía la entidad y el poco margen de beneficios conseguido. Siempre primó la intención de mantener el precio de las entradas más baratas, a favor del cultivo de la afición de la música sinfónica en Madrid. 


\section{NOTAS}

1 Luis Enrique Otero Carvajal, "Las ciudades en la España de la Restauración (1868-1939)", en España entre repúblicas 1868-1939, vol. 1 (Guadalajara: Asociación de Amigos del Museo Provincial de Castilla-La Mancha, 2005), 29.

2 Fernando Vicente Albarrán, Borja Carballo Barral y Rubén Pallol Trigueros, "Del taller a la gran fábrica, del ultramarinos a la gran empresa. La evolución del mercado de trabajo madrileño entre 1860 y 1930", en Ayeres en discusión: temas claves de historia contemporánea hoy. IX Congreso de Historia Contemporánea, ed. Nicolás Martín y González Martínez (Murcia: Universidad de Murcia, 2008), 3.

3 Cfr. Antonio Fernández, "La población madrileña entre 1876 y 1931 . El cambio de modelo demográfico", en La sociedad madrileña durante la Restauración (1876-1931), vol. 1, ed. Bahamonde y Otero (Madrid: Comunidad de Madrid, 1989), 29-76.

4 Cfr. Ángel Fernández García, "La evolución social de Madrid en la época liberal (1834-1900)", en Arquitectura y espacio urbano de Madrid en el siglo XIX, ed. Carmen Priego (Madrid: Museo de Historia de Madrid, 2008), 10-29.

5 Ángel Bahamonde y Julián Toro, Burguesía, especulación y cuestión social en el Madrid del siglo XIX (Madrid: Siglo XX, 1978), 42-43.

6 Cfr. Vicente Albarrán, Carballo Barral y Pallol Trigueros, "Entre palacetes y corralas: proceso de segregación socioespacial en el nuevo Madrid (1860-1905)", en Ayeres en discusión: temas claves de historia contemporánea hoy, 21.

7 Luis Moya, "Cuando la ciudad parte de una matriz teórica", en Arquitectura y espacio urbano de Madrid en el siglo XIX, ed. Carmen Priego (Madrid: Museo de Historia de Madrid, 2008), 49. Cfr. también: Otero Carvajal, Luis Enrique y Pallol Trigueros, Rubén. 2009. "El Madrid moderno: capital de una historia urbana en transformación, 18601931", en Historia Contemporánea 39, 541-588; y Carballo Barral, Borja; Pallol Trigueros, Rubén y Vicente Albarrán,
Fernando, El Ensanche de Madrid. Historia de una capital, (Madrid: Editorial Complutense, 2008).

8 Cfr. Germán Rueda, 2013. "Cuatro condicionantes de la vida social de los españoles del siglo XIX". Revista de Estudios Extremeños, LXIX, nº I: 124.

9 Vicente Albarrán, Carballo Barral y Pallol Trigueros. 2010. "Inmigración y mercado en el Madrid de la segunda mitad del siglo XIX". Revista de Demo-

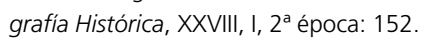

10 Recordemos la Menegilda de La Gran Vía (1886), figura representativa de todas las "fregatrices" coetáneas, a la que pronto tiene que dar la réplica sobre las tablas el ama, Doña Virtudes. Cfr. La Gran Vía, edición crítica de Cortizo y Sobrino, (Madrid: ICCMU, 1996).

11 Sirva como ejemplo entre cientos, el anuncio publicado el 21-9-1862, en el Diario oficial de avisos de Madrid, solicitando ama de cría "que tenga buena leche y que esté sana. [...] Se le darán ocho duros mensuales", p. 4.

12 Cfr. Carmen Sarasúa, Criados, nodrizas y amo: el servicio doméstico en la formación del mercado de trabajo madrileño, 1758-1868, (Madrid: Siglo XXI, 1994).

13 "Muchas mujeres se empleaban en tareas por horas, cosiendo en sus casas para algún gran taller o acudiendo esporádicamente al río para trabajar como lavanderas, realizando trabajos industriales a domicilio como guarnecedoras en fábricas de zapatos o colocándose como asistentas por horas". Vicente Albarrán, Carballo Barral y Pallol Trigueros, "Del taller a la gran fábrica, del ultramarinos a la gran empresa. La evolución del mercado de trabajo madrileño entre 1860 y 1930", 11.

14 A finales de siglo, parece que el suelo de las costureras había subido hasta cinco reales diarios. Germán Rueda, "Cuatro condicionantes de la vida social de los españoles del siglo XIX", 124.

15 Jorge Uría, 2001. "Lugares para el ocio. Espacio público y Espacios recreativos en la Restauración española". Historia Social, n 41, 91.

16 Luis Moya, "Cuando la ciudad parte de una matriz teórica", 51.
17 Luis Enrique Otero Carvajal, "Las ciudades en la España de la Restauración (1868-1939)", 29.

18 Luis Enrique Otero Carvajal y Rubén Pallol Trigueros, "El Madrid moderno, capital de una España urbana en transformación (1860-1931)", 560.

19 Robert Marrast, José de Espronceda y su tiempo (Barcelona: Crítica, 1989), 570.

${ }^{20} M^{a}$ Rosa Cervera Sardá, "Hierro y arquitectura en el Madrid del siglo XIX", en Arquitectura y espacio urbano de Madrid en el siglo XIX, ed. Carmen Priego (Madrid: Museo de Historia de Madrid, 2008), 58.

21 Luis Enrique Otero Carvajal, 2016. "La sociedad urbana y la irrupción de la modernidad en España, 1900-1936". Cuaderno de historia contemporánea, 38, número especial, 257.

22 José de Castro y Serrano, Cartas trascendentales escritas a un amigo de confianza. Carta III. (Madrid: Imp. de Fortanet, 1887), 61.

23 Tomás Luceño y Becerra, El teatro moderno, (Madrid: Imp. Española, 1870), 21

24 Las familias trabajadoras madrileñas de mediados de siglo estaban marcadas por "la escasez, por la necesidad de juntar varios salarios para llegar a final de mes y por el acento que se ponía en la unión para conseguir el incierto objetivo de la supervivencia". Vicente Albarrán, Carballo Barral y Pallol Trigueros. 2010. "Inmigración y mercado en el Madrid de la segunda mitad del siglo XIX". Revista de Demografía Histórica, XXVIII, I, 2 2a época, 162.

25 "Estrechamente informadas por los trabajadores domésticos, las clases populares incorporan ciertas prácticas de la cultura burguesa bajo una forma particular de clase". Francesc Calvo Ortega, 2017. "Las intimidades colectivas de la clase obrera. Vida urbana y cultura popular en las ciudades de principios del siglo XX". Humanidades. Revista de Estudios Generales, Universidad de Costa Rica. Vol. 7(1), 6.

${ }^{26}$ Cfr. $M^{a}$ Encina Cortizo, Emilio Arrieta. De la ópera a la zarzuela (Madrid: ICCMU, 1998), 368 y ss.

${ }^{27}$ Castro y Serrano, Cartas trascendentales, Carta II, 34. 
${ }^{28}$ Cortizo, Emilio Arrieta, 368 y ss.

${ }^{29}$ Cfr., entre otras, León Boyd [seudónimo de Casal, Enrique], Fiestas aristocráticas 1913-14, (Madrid: Admon. Martín de los Heros: 1914).

30 En junio de 1863, los dos payasos y Wilthoyne y Secchi, del TeatroCirco Price, tienen gran éxito con funciones en las que parodian Norma de Bellini. La Discusión, 2-7-1863, p. 3.

31 "Eclipses. Gacetilla", La España, 18-11-1849, p. 4. El gacetillero se refiere a la soprano Fanny Tacchinardi Persiani, una de las mejores cantantes belcantista y la mejor intérprete de la década de los cuarenta del personaje protagonista de Lucia di Lammermoor; y al barítono también italiano Giorgio Ronconi, primer Nabucco en el estreno de la ópera homónima de Verdi en la Scala milanesa en 1842. Ambos formaron parte de la compañía que José de Salamanca reunió en la década de 1840 en el Teatro del Circo.

32 Cfr. Ma Aurelia Díez Huerga. 2006. "Salones, bailes y cafés: costumbres socio-musicales en el Madrid de la reina castiza (1833-1868)". Anuario Musical, $\mathrm{n}^{\circ} 61$ (enero-diciembre), 189-201. Y Celsa Alonso, La Canción Lírica Española en el siglo XIX, (Madrid: ICCMU-SGAE, 1998).

33 "El piano en familia". Revista y Gaceta Musical, Madrid, Año II, n 23, 8-6-1866, p. 100.

${ }^{34}$ Cfr. WV. AA. Sociedades musicales en España. Siglos XIX y XX, editado Cortizo y Sobrino. Cuadernos de Música Iberoamericana. Vols. 8 y 9, número monográfico, (Madrid: ICCMU, 2001).

${ }_{35} \mathrm{M}^{\mathrm{a}}$ Encina Cortizo, La Restauración de la Zarzuela en el Madrid del siglo XIX (1832-1856), (Madrid, Tesis doctoral, Universidad Complutense: 1993).

36 Todavía en los años cuarenta, encontramos funciones misceláneas, que mantienen la estructura habitual en los siglos previos, caracterizada por la inclusión de formas breves -sainetes, bailes, tonadillas...- en los intermedios de los actos de una obra grande. $E$ incluso, la función inaugural del teatro de la Zarzuela, en octubre de 1856, es todavía una función mixta y variada.

37 En España no hay costumbre de que las damas se muevan de su sitio du- rante los entreactos, a diferencia de lo que sucede en París, Londres o Berlín, a pesar de que las funciones de ópera pueden durar entre cuatro y seis horas, sobre todo, a partir de la llegada del repertorio wagneriano.

38 Melchor Almagro San Martín, Biografía del 1900 (Granada: Universidad de Granada: 2013) 234-235. Se trata de una reedición de la obra original, publicada en Madrid en 1943. Al "pesetero" se refiere Enrique Sepúlveda en La vida en Madrid en 1887 (Madrid: Est. Tip. de Ricardo Fe, 1989), 18-19.

${ }^{39}$ No se debe confundir este teatro, destruido por un incendio en 1876, con el Teatro-Circo de Paul o Pol, en la calle Barquillo, que fue construido por el propio Paul Laribeau un poco más tarde, en 1847, y que tendrá vida en la segunda mitad del siglo, como veremos. Cfr. Ángel Luis Fernández Muñoz, Arquitectura teatral en Madrid (Madrid: Ayuntamiento de Madrid, ed. El Avapiés: 1989).

40 Cfr. Emilio Casares, La ópera en España. Procesos de recepción y modelos de creación. II. Desde la Regencia de María Cristina hasta la Restauración Alfonsina (1833-1874), (Madrid: ICCMU: 2018), 129 y ss.

${ }^{41}$ Ésta cita y la anterior: "Inauguración del Teatro de la Zarzuela". El Clamor Público, 12-10-1856, p. 3.

42 "La Zarzuela". El Enano, Madrid, 14-10-1856, p. 4.

43 "Inauguración del Teatro de la Zarzuela". El Clamor Público, 12-101856, p. 3.

44 Fuente: Luis García Martín, Manual de teatros y espectáculos de Madrid (Madrid: Cristóbal González: 1861), 53-54.

45 Víctor Ruiz Albéniz ("Chispero"), Teatro Apolo. Historial, anecdotario y estampas madrileñas de su tiempo (1873-1929). "Estampa IV", s/p. (Madrid: Prensa Ibérica: 1953).

46 "Asistir a la función inaugural [de la Zarzuela] era ya una verdadera necesidad, de que no se podía prescindir entre gentes de cierta clase". Adán. "Teatros". Álbum de señoritas, 16-101856, p. 7.

47 José Ignacio Suárez García. 2007. "La recepción de la obra de Richard Wagner en Madrid entre 1877 y 1893", Cuadernos de Música Iberoamericana, vol. 14, 127.

48 Fragmento de un comentario sobre el Teatro del Circo Barcelonés publicado en el Diario de Barcelona, 27-11857, p. 2.

49 Ruiz Albéniz, Teatro Apolo, "Estampa IV", s./p.

50 Juan P. Arregui. 2005. "Luminotecnia teatral en la primera mitad del siglo XIX: de la herencia barroca a la introducción del gas". Stichomythia, Revista de Teatro Español Contemporáneo, 3, 28.

51 Cfr. Ma Encina Cortizo y Ramón Sobrino, "Main changes in the Spanish Way of Life after the Second Industrial Revolution: images of modernity through the Género Chico (18701914)", en Music and the Second Industrial Revolution, ed. Massimiliano Sala. (Turnhout: Brepols, 2019), 75.

52 Manuel Osorio y Bernard, "Causas de la decadencia actual del teatro español". Escenas contemporáneas, año $\mathrm{Vl}, 3^{\mathrm{a}}$ época, $n^{\circ}$ 6, 20-1-1862, p. 126.

53 Ángel Fernández de los Ríos, Guía de Madrid. Manual del madrileño y del forastero (Madrid: Oficinas de La Ilustración Española y Americana: 1876), 763.

54 Pedro Villa Mínguez, "Precios alimentarios y nivel de vida en Madrid (1851-1890)", en Madrid en la Sociedad del siglo XIX, vol. 2. Capas populares $y$ conflictividad social. Abastecimiento, población y crisis de subsistencia. Cultura y mentalidades, ed. Otero Carvajal y Bahamonde (Madrid: Comunidad de Madrid y Revista ALFOZ CIDUR: 1986), 287. Parecida cantidad maneja Rueda, "Cuatro condicionantes de la vida social de los españoles del siglo XIX", 117.

55 El ama de cría procede generalmente de la zona cantábrica, siendo especialmente valoradas las pasiegas. Normalmente, anhelaban regresar con su familia y terminado el tiempo de cría, por tanto, no estaban en Madrid con intención de alternar, sino para ahorrar la mayor cantidad de dinero posible.

${ }^{56}$ Castro y Serrano, Cartas trascendentales, Carta II, 30.

57 Javier de Santiago Fernández, "Antecedentes del sistema monetario 
de la peseta", en VII Jornadas Cientificas Sobre Documentación Contemporánea (1868-2008) (Madrid: Universidad Complutense, 2008), 371.

${ }^{58}$ Cfr. Ibid., 44 y ss.

59 El Circo se divide en cuatro grandes categorías, relacionadas con la altura -platea (nuestro actual patio de butacas), entresuelo, anfiteatro principal y anfiteatro segundo-.

60 En el mismo folleto, Arderius ofrece también un abono por tan solo treinta representaciones, mucho más asequible.

${ }^{61}$ [Francisco Arderius], Función de desagravios a las Señoras de Madrid. Temporada de los Bufos, 1869-1870. Teatro del Circo. IV Campaña teatral (Madrid: Imp. Española, 1869).

62 Demetrio Castro. 2008. "Tipos y aires. Imágenes de lo español en la zarzuela". Ayer 72 (4):1, 71.

63 Los Anuarios estadísticos de España de los años 1859 a 1867 fueron publicados por la Comisión Estadística General del Reino (Madrid: Imp. Nacional). El del año 1866-67 lo publicó la Imp. de Minuesa de los Ríos en 1870. Véase también la Fig. 4, algunos de cuyos resultados se publicaron en la Gaceta de Madrid, 12-11-1862.

${ }^{64}$ A ese crecimiento contribuyó no poco la liberalización de la actividad teatral que impuso el Reglamento de 1849, permitiendo que fuera el mercado el que rigiera la actividad, apareciendo así la figura del empresario persiguiendo el beneficio. Cfr. Jesús Rubio, "El teatro en el siglo XIX" (II), en Historia del Teatro español, II, siglos XVIII-XIX, ed. José María Díez Borque (Madrid: Taurus, 1988).

65 Carlos Serrano. 2010. "Teatro, deporte y corrida: hacia el espectáculo de masas en la España Isabelina (18591867)". Revista de Estudios Taurinos, $\mathrm{n}^{\circ}$ 28, Sevilla, 119.

66 Anuario administrativo de la provincia de Madrid para el año 1868 (Madrid: Oficina tip. del Hospicio, 1868 y 1869), 359.

67 Gil Blas, 28-3-1867, p. 1.

68 Véase el cuadro de cafés-cantantes del Anuario en: Enrique Mejías. 2017. "Las raíces isabelinas del teatro por horas y su primer repertorio: en torno a los orígenes del género chico".
Cuadernos de Música Iberoamericana, vol. 30 (enero-diciembre), 95.

69 Luis Rivera, "Lo que corre por ahí". Gil Blas, 2ª época, 28-3-1867, p. 1.

70 Ángel Fernández de los Ríos, Guía de Madrid, 573.

71 En efecto contrario, años después, hacia 1900, los aristócratas que querían acudir a la cuarta función de Apolo tras salir del Real sin sentirse intimidados ante su atuendo de gala, conforman la Sociedad de palcos que, a cambio de una cuota, les garantizaba un asiento en un palco entre iguales. Tal y como relata Ruiz Albéniz, dicha Sociedad de palcos llegó a tener palco en cinco teatros en 1910: Real, Comedia, Princesa, Apolo y Eslava. "Estampa primera. La sociedad de palcos". Teatro Apolo, s/p.

72 Archivo Histórico Nacional. Consejos. Leg. 11.388, n 166.

73 Cortizo, Emilio Arrieta, 363.

74 "Ministerio de Hacienda. Reglamento general para la imposición, administracion y cobranza de la Contribución industrial". Gaceta de Madrid, 29-3-1870, pp. 1-2.

75 Se conservan el Reglamento para la Sociedad de los Campos Elíseos de Madrid (Madrid: Imp. y Estereotipia Española, 1861); y la Memoria de dicho proyecto, firmada por Casadesús, donde se recogen los gastos de inversión, y los beneficios que se esperan ya del primer verano de explotación, el de 1861.

76 Carmen Ariza Muñoz, "Los jardines madrileños en el siglo XIX", en Madrid en la sociedad del siglo XIX, vol. 2, ed. Otero Carvajal y Bahamonde Magro (Madrid: Consejería de Cultura de la Comunidad de Madrid, Revista ALFOZ CIDUR, 1986), 535.

77 Juan Belza, "Los Campos Elíseos". El Periódico llustrado, año I, $n^{\circ}$ 12, 25-5-1865, p. 5

78 Mauricio Sánchez Menchero. 2009. "Cinco cuadros al fresco. Los jardines de recreo de Madrid (18601890)". Culturales, vol. V, no 9 (enerojunio), 146-147. Lamentablemente, el proyecto dejó de ser rentable, y tras cierto abandono, fue destruido en 1881.
79 "Sección de noticias". La Violeta, 17-4-1864, p. 3.

${ }^{80}$ En las funciones de baile, la orquesta estaba dirigida por José Vicente Arche.

81 "Espectáculos de hoy. Campos Elíseos". La Correspondencia de España, 19-6-1864, p. 4. Llega un momento, que es necesario ayudar al consumidor a elegir la atracción a la que desea asistir, evitando la confusión; Sánchez Menchero recoge cómo en 1867, "Joaquín Gaztambide instala un anuncio transparente en lo más alto del centro de la Puerta de Alcalá para informar de los programas diarios" a los espectadores. "Cinco cuadros al fresco". Culturales, 151.

82 Mariano Soriano Fuertes, Calendario Histórico musical para el año de 1873 (Madrid: Imp. de la Biblioteca de Instrucción y Recreo, 1872), 61.

83 Barbieri, F. A. "La verdad en su lugar". La Correspondencia Musical, 8-11-1882, p. 3.

${ }^{84}$ Cfr. Cortizo, Emilio Arrieta. De la ópera a la zarzuela, 327. Este teatro era el único de toda Europa que llevaba el nombre del compositor de Pésaro.

${ }^{85}$ Ramón Sobrino. 2006. "Joaquín Gaztambide (1822-1870). Director de orquesta". Príncipe de Viana, $\mathrm{n}^{\circ} 238$, 641.

${ }^{86}$ Cfr. Barbieri, "La verdad en su lugar". La Correspondencia Musical, 8-11-1882, p. 3.

${ }^{87}$ La orquesta era grande -unos 70 profesores, con 44 instrumentistas de cuerda, 3 arpas, 4 trompas, 3 trombones...-; y entre los instrumentistas, destacan nombres que luego conformarán con Barbieri la Sociedad de Conciertos, como los violinistas Pérez, Jiménez y Arche, los violonchelistas Campo y Casellas, el contrabajista Muñoz, el flautista Sarmiento, el clarinetista Fischer, o los hermanos Melliez, Camillo al fagot y Agustín al cornetín. Cfr. La Libertad, 7-06-1864, 4. Cfr. Ramón Sobrino, "La música sinfónica en el siglo XIX", en La Música en España en el siglo XIX, ed. Casares y Alonso (Oviedo: Servicio de publicaciones de la universidad de Oviedo, 1995), 279-323.

88 Nemesio Fernández Cuesta. "Revista de la semana". El Museo Universal (Madrid), 3-7-1864, p. 1. 
89 De 5 de la mañana, hora de apertura, a 5 de la tarde, la entrada costaba sólo la mitad, 2 reales; a partir de esa hora, el precio de entrada se duplicaba.

90 Jesús Cruz. 2015. "Símbolos de modernidad: la historia olvidada de los jardines de recreo en la España del siglo XIX". Historia social, n $83,38$.

91 Benito Pérez Galdós. "Folletín. Revista de la semana". La Nación, 226-1865, p. 1

92 Sobre estos jardines, véanse los trabajos de Carmen Ariza Muñoz.

93 Cfr. Javier Barreiro. 2010. "Los primeros chotis españoles". Anales del Instituto de estudios madrileños, 37-42.

94 "Gacetilla". La España, 18-111849, p. 4.

$95 \mathrm{M}$ [esonero] R[omanos], R. de. "Crónica matritense de octubre". La Ilustración, n 44, 1-11-1851, p. 1.

96 "Gacetilla". La España, 17-111850, p. 4.

97 También tenían orquesta el Recreo o Capellanes. Mejías, "Las raíces isabelinas del teatro por horas y su primer repertorio: en torno a los orígenes del género chico", 99.

98 "Gacetilla". La España, 30-111853, p. 4.

99 "Espectáculos". La España, 17-31859 , 4. Probablement el horario fuera alternando de año a año, pues en 1868 , la Constante celebra su baile de ocho a una de la noche; y la Juventud Española, de tres a siete de la tarde. "Espectáculos". La España, 11-1-1868, p. 4.

100 Cortizo, Emilio Arrieta, 336 y ss.

101 "Hay, además, la sociedad de la Juventud española, en los Basilios, y el Circo de Paul, que se puebla de bailarines las tardes y noches de los días festivos". "Gacetilla. Jaleo largo". La España, 3-1-1854, p. 4.

$102 \quad$ "Gacetilla. " $¡ Y$ Ya es demasiada afición!". La España, 17-3-1859, p. 4.

103 La personificación de este baile había aparecido ya en El paraíso en Madrid, gacetilla lírica en tres actos y en verso de Luis Rivera, puesta en música por Antonio Reparaz y estrenada en el teatro del Circo la noche del 21 de diciembre de 1860 . Y reaparecerá en la revista cómico-lírico fantástico callejera $L a$
Gran Vía (1886), como protagonista de la apoteosis de la revista de Felipe Pérez y González, Federico Chueca y Joaquín Valverde, cantando el Chotis del 'Elisedo'. Cfr. La Gran Vía, edición crítica Cortizo y Sobrino (Madrid: ICCMU, 1996).

104 Ésta cita y la anterior: Fernández Cuesta, Nemesio. "Revista semanal". El Museo Universal, 12-81860, p. 2.

105 "Espectáculos". La Iberia, 8-12-1863, p. 3.

106 Pedro Montoliù Camps, Madrid Villa y Corte. Historia de una ciudad, vol. 1 (Madrid: Sílex, 1996), 203.

107 "Apéndice". Guía de Forasteros. Año Económico de 1871-72 (Madrid, Imp. Nacional, 1871), 133.

108 Archivo Histórico Nacional. Consejos. Leg. 11.405, nos 108 a 160. Parte de los datos se publicaron en la Gaceta de Madrid, 12-11-1862.

109 Albergaba diversas sociedades de baile; por ejemplo, en septiembre de 1862, acogía los bailes de la Juventud española de 15 a 19 hs.; y la Constante de 20 a las 24 hs. Diario Oficial de Avisos de Madrid, 21-9-1862, p. 4.

110 "Jardín de recreo en el paseo de Recoletos", que ofrece bailes los domingos, a las 17:30, con fuegos artificiales. Diario Oficial de Avisos de Madrid, 21-9-1862, p. 4.

111 Diario oficial de avisos de Madrid, 06-7-1862, p. 4.

112 "Gran jardín de recreo en la puerta de Santa Bárbara, frente a la Real Fábrica de Tapices". Baile los domingos a las 17:00 h., seguido de fuegos artificiales. Diario Oficial de Avisos de Madrid, 21-9-1862, p. 4.

113 Luis García Martín, "Bailes. Lo que fue el año cómico 1860-61", Manual de teatros y espectáculos de Madrid (Madrid: Imp. Nicolás González, 1860), 69.

114 Este baile se celebraría de siete a doce de la noche. "Diversiones públicas". Diario Oficial de Avisos de Madrid, 6-7-1862, p. 4.

115 Diario Oficial de Avisos de Madrid, 21-9-1862, p. 4.

116 "Gacetilla. Observaciones de un desocupado". La España, 4-91864,p. 4.
117 García Martín, Manual de teatros y espectáculos de Madrid, 5354.

118 El clamor público, 3-11862, p. 3.

119 Tanto en repositorio EUROPEANA como en CERES del Ministerio de Cultura, se identifica erróneamente el baile del cuadro como el de los Campos Elíseos, situándolo en la Calle de Alcalá, pero el título del cuadro aclara perfectamente que se trata de El Paraíso.

120 Fuente: Diario Oficial de Avisos de Madrid, 14-8-1862, p. 4.

121 "Espectáculos". La Iberia, 8-12-1863, p. 3.

122 Entre 1860 y 1861, los editores Carrafa y Sanz publican una colección de danzas por entregas denominada "El Eliseo madrileño y Salón de Capellanes, colección de las más aplaudidas piezas de música que se ejecutan en los bailes públicos de la Corte", que reúne danzas de moda, para piano, a veces a cuatro manos, con indicaciones coreográficas finales. Muchas de ellas parte de temas operísticos de Giuseppe Verdi.

123 Pérez Galdós, Benito. "Folletín". La Nación, 19-11-1865, pp. 1-2.

124 Cfr. Sánchez Menchero, "Cinco cuadros al fresco...", Culturales, 151 y ss.

$125 \quad$ Nació como sociedad sinfónico-coral, pero a partir de 1868 renunció al coro.

126 Ramón Sobrino, "La música sinfónica en el siglo XIX", 161-194.

$127 \quad$ Además, la Sociedad de Conciertos ofreció un concierto el 23 de septiembre en el Teatro del Circo a beneficio de la Sociedad Artístico-Musical de Socorros Mutuos.

128 "Estado demostrativo de ingresos y gastos en los conciertos verificados por la Orquesta dirigida por el Sr. Barbieri en los Jardines de Apolo en el presente año". Archivo de la Sociedad de Conciertos de Madrid. Ramón Sobrino. 1992. El sinfonismo español en el S. XIX. La Sociedad de Conciertos de Madrid. Tesis doctoral inédita. Universidad de Oviedo. Apéndice, s/p. 
Prácticas y espacios musicales de una ciudad burguesa en desarrollo

\section{REFERENCIAS}

Almagro San Martín, Melchor. 2013. Biografía del 1900. Granada: Universidad de Granada.

Alonso, Celsa. 1998. La Canción Lírica Española en el siglo XIX. Madrid: ICCMU.

Arderius, Francisco. 1869. Función de desagravios a las Señoras de Madrid. Madrid: Imp. Española.

Ariza Muñoz, Carmen. 1986. "Los jardines madrileños en el siglo XIX.". En Madrid en la sociedad del siglo XIX (2). Capas populares y conflictividad social. Abastecimiento, población y crisis de subsistencias. Cultura y mentalidades, J. Otero Carvajal y Bahamonde Magro, eds., 519-537. Madrid: Consejería de Cultura de la Comunidad de Madrid.

Ariza Muñoz, Carmen. 1990. Los Jardines del Buen Retiro de Madrid. Madrid: Lunwerg.

Arregui, Juan P. 2005. "Luminotecnia teatral en la primera mitad del siglo XIX: de la herencia barroca a la introducción del gas." Stichomythia, Revista de Teatro Español Contemporáneo 3: 28.

Bahamonde Magro, Ángel, y Julián Toro Mérida. 1978. Burguesía, especulación y cuestión social en el Madrid del siglo XIX. Madrid: Siglo XX.

Barreiro, Javier. 2010. "Los primeros chotis españoles." Anales del Instituto de estudios madrileños 50: 37-42.

Boyd, León [seudónimo de Casal, Enrique]. 1914. Fiestas aristocráticas 1913-14. Madrid: Admon. Martín de los Heros.

Calvo Ortega, Francesc. 2017. "Las intimidades colectivas de la clase obrera. Vida urbana y cultura popular en las ciudades de principios del siglo XX." Humanidades. Revista de Estudios Generales 7(1): 6. https://doi.org/10.15517/h. v7i1.27622

Carballo Barral, Borja, Pallol Trigueros, Rubén, y Fernando Vicente Albarrán. 2008. El Ensanche de Madrid. Historia de una capital. Madrid: Editorial Complutense.

Casares, Emilio. 2018. La ópera en España. Procesos de recepción y modelos de creación. II. Desde la Regencia de María Cristina hasta la
Restauración Alfonsina (1833-1874). Madrid: ICCMU.

Castro y Serrano, José de. 1887. Cartas trascendentales escritas a un amigo de confianza. Madrid: Imp. de Fortanet.

Castro, Demetrio. 2008. "Tipos y aires. Imágenes de lo español en la zarzuela." En Dossier Espectáculo y sociedad en la España contemporánea, Demetrio Castro y Edward Baker, eds. Ayer 72 (4-1): 57-82.

Cervera Sardá, Ma Rosa. 2008. "Hierro y arquitectura en el Madrid del siglo XIX.". En Arquitectura y espacio urbano de Madrid en el siglo XIX, Carmen Priego, ed., 56-83. Madrid: Museo de Historia de Madrid.

Cortizo, Ma Encina. 1998. Emilio Arrieta. De la ópera a la zarzuela. Madrid: ICCMU.

Cortizo, Ma Encina. 1993. La Restauración de la Zarzuela en el Madrid del siglo XIX (1832-1856). Tesis doctoral. Madrid: Universidad Complutense. https://doi.org/10.2307/20797006

Cortizo, M $M^{a}$ Encina, y Ramón Sobrino. 2019. "Main changes in the Spanish Way of Life after the Second Industrial Revolution: images of modernity through the Género Chico (18701914)." In Music and the Second Industrial Revolution, Massimiliano Sala, ed. Colección Music, Science and Technology, 2, 70-95 Turnhout: Brepol.

Cruz, Jesús. 2015. "Símbolos de modernidad: la historia olvidada de los jardines de recreo en la España del siglo XIX." Historia social 83: 37-54.

Díez Huerga, Ma Aurelia. 2006. "Salones, bailes y cafés: costumbres socio-musicales en el Madrid de la reina castiza (1833-1868)." Anuario Musical 61 (enero-diciembre):189-201. https:// doi.org/10.3989/anuariomusical.2006.61.10

Ezama Gil, Ángeles. 2008. "Arte y literatura en los salones femeninos del siglo XIX: el salón de Trinidad Scholtz. La moda de los cuadros vivos." . En Sociedad de Literatura Española del Siglo XIX, IV Coloquio: La Literatura Española del Siglo XIX y las artes, Jean François Botrel, Marisa Sotelo, Enrique Rubio, Laureano Bonet, Pau Miret, Virginia Trueba y Noemi Carrasco, 
eds., 111-127. Barcelona: Universitat de Barcelona/PPU.

Fernández de los Ríos, Ángel. 1876. Guía de Madrid. Manual del madrileño y del forastero. Madrid: Oficinas de La Ilustración Española y Americana.

Fernández García, Ángel. 2008. "La evolución social de Madrid en la época liberal (18341900)." En Arquitectura y espacio urbano de Madrid en el siglo XIX, Carmen Priego, ed., 10-29. Madrid: Museo de Historia de Madrid.

Fernández Muñoz, Ángel Luis. 1989. Arquitectura teatral en Madrid. Madrid: Ayuntamiento de Madrid, ed. El Avapiés.

Fernández, Antonio. 1989. "La población madrileña entre 1876 y 1931. El cambio de modelo demográfico." En La sociedad madrileña durante la Restauración (1876-1931), Bahamonde y Otero, ed., vol. 1, 29-76. Madrid: Comunidad de Madrid.

Freire, Ana María. 2002. "Salones y teatros de sociedad en el siglo XIX." En Espacios de la comunicación literaria, Álvarez Barrientos, ed., 149-160. Madrid: CSIC.

García Martín, Luis. 1860. Manual de teatros y espectáculos de Madrid. Madrid: Cristóbal González.

Luceño y Becerra, Tomás. 1870. El teatro moderno. Madrid: Imp. Española.

Marrast, Robert. 1989. José de Espronceda y su tiempo. Barcelona: Crítica.

Mejías, Enrique. 2017. "Las raíces isabelinas del teatro por horas y su primer repertorio: en torno a los orígenes del género chico." Cuadernos de Música Iberoamericana 30 (enerodiciembre): 87-109. https://doi.org/10.5209/ cmib. 58564

Montoliù Camps, Pedro. 1996. Madrid Villa y Corte. Historia de una ciudad, vol. 1. Madrid: Sílex.

Moya, Luis. 2008. "Cuando la ciudad parte de una matriz teórica.". En Arquitectura y espacio urbano de Madrid en el siglo XIX, Carmen Priego, ed., 30-37. Madrid: Museo de Historia de Madrid.
Otero Carvajal, Luis Enrique. 2007. "Las ciudades en la España de la Restauración (1868-1939)." . En España entre repúblicas 1868-1939, Actas de las VII Jornadas de Investigación de CastillaLa Mancha sobre investigación en Archivos, vol. 1, 27-80. Guadalajara: Asociación de Amigos del Museo Provincial de Castilla-La Mancha.

Otero Carvajal, Luis Enrique, y Rubén Pallol Trigueros. 2009. "El Madrid moderno: capital de una historia urbana en transformación, 18601931." Historia Contemporánea 39: 541-588.

Otero Carvajal, Luis Enrique. 2016. “La sociedad urbana y la irrupción de la modernidad en España, 1900-1936." Cuaderno de historia contemporánea 38: 255-283. https://doi. org/10.5209/chco.53678

Pérez y González, Felipe, Chueca, Federico, y Joaquín Valverde. 1996. La Gran Vía (Edición crítica Cortizo y Sobrino). Madrid: ICCMU.

Rubio, Jesús. 1988. "El teatro en el siglo XIX (II) (1845-1900)." En Historia del Teatro español, II, siglos XVIII-XIX, José María Díez Borque, dir., 625-751. Madrid, Taurus. https://doi. org/10.3828/bhs.68.4.544

Rueda, Germán. 2013. "Cuatro condicionantes de la vida social de los españoles del siglo XIX." Revista de Estudios Extremeños LXIX, n I: 95-140.

Ruiz Albéniz, Víctor. "Chispero". 1953. Teatro Apolo. Historial, anecdotario y estampas madrileñas de su tiempo (1873-1929). Madrid: Prensa Ibérica.

Salaun, Serge. 2001. "La sociabilidad en el teatro (1890-1915)." Historia Social 41: 128-129.

Sánchez Menchero, Mauricio. 2009. "Cinco cuadros al fresco. Los jardines de recreo de Madrid (1860-1890)." Culturales V, nº 9 (enero-junio): 141-168.

Santiago Fernández, Javier de. 2008. "Antecedentes del sistema monetario de la peseta." En VII Jornadas Científicas Sobre Documentación Contemporánea (1868-2008), 369-390. Madrid: Universidad Complutense de Madrid.

Sarasúa, Carmen. 1994. Criados, nodrizas y amos: el servicio doméstico en la formación del 
Prácticas y espacios musicales de una ciudad burguesa en desarrollo

mercado de trabajo madrileño, 1758-1868. Madrid: Siglo XXI. https://doi.org/10.1017/ s021261090000570x

Serrano, Carlos. 2010. "Teatro, deporte y corrida: hacia el espectáculo de masas en la España Isabelina (1859-1867)". Revista de Estudios Taurinos, n² 28, Sevilla, 111-131.

Sobrino, Ramón. 1992. El sinfonismo español en el S. XIX. La Sociedad de Conciertos de Madrid. Tesis doctoral inédita. Universidad de Oviedo. https://doi.org/10.2307/20797001

Sobrino, Ramón. 1995. "La música sinfónica en el siglo XIX." En La Música Española en el siglo XIX, Casares Rodicio y Alonso, eds., 161-194. Oviedo: Servicio de Publicaciones de la U. de Oviedo. https://doi.org/10.4067/ s0716-27901998018900015

Sobrino, Ramón. 2006. "Joaquín Gaztambide (1822-1870). Director de orquesta." Príncipe de Viana 67, n² 238. Conmemoración del VIII Centenario de la Chantría de la Catedral de Pamplona como dignidad eclesiástica (12062006). María Gembero, ed., 633-654.

Soriano Fuertes, Mariano. 1872. Calendario Histórico musical para el año de 1873. Madrid: Imp. de la Biblioteca de Instrucción y Recreo.

Suárez, José Ignacio. 2007. "La recepción de la obra de Richard Wagner en Madrid entre 1877 y 1893." Cuadernos de Música Iberoamericana 14: 73-142.

Uría, Jorge. 2001. “Lugares para el ocio. Espacio público y Espacios recreativos en la Restauración española." Historia Social 41: 89-112.

Vicente Albarrán, Fernando, Carballo Barral, Borja, y Rubén Pallol Trigueros. 2008. “Del taller a la gran fábrica, del ultramarinos a la gran empresa. La evolución del mercado de trabajo madrileño entre 1860 y 1930." En Ayeres en discusión: temas claves de historia contemporánea hoy. IX Congreso de Historia Contemporánea, Nicolás Marín y González Martínez, eds., 1-19. Murcia: Universidad de Murcia.

Vicente Albarrán, Fernando, Carballo Barral, Borja, y Rubén Pallol Trigueros. 2008. “Entre palacetes y corralas: proceso de segregación socioespacial en el nuevo Madrid (18601905)." En Ayeres en discusión: temas claves de historia contemporánea hoy. IX Congreso de Historia Contemporánea, Nicolás Marín y González Martínez, 1-20. Murcia: Universidad de Murcia.

Vicente Albarrán, Fernando, Carballo Barral, Borja, y Rubén Pallol Trigueros. 2010. “Inmigración y mercado en el Madrid de la segunda mitad del siglo XIX." Revista de Demografía Histórica 28, $\mathrm{n}^{\circ} 1$ (2 $2^{\mathrm{a}}$ época): 131-166.

Villa Mínguez, Pedro. 1986. "Precios alimentarios y nivel de vida en Madrid (1851-1890).". En Madrid en la Sociedad del siglo XIX, vol. 2, Capas populares y conflictividad social. Abastecimiento, población y crisis de subsistencia. Cultura y mentalidades, Otero Carvajal y Bahamonde, 267-288. Madrid: Comunidad de Madrid y Revista ALFOZ CIDUR. https://doi. org/10.1017/s021261090001524x

V. AA. 2001. Sociedades musicales en España. Siglos XIX y XX. Cuadernos de Música Iberoamericana, vols. 8 y 9 (número monográfico), Cortizo y Sobrino, eds. Madrid: ICCMU. 